\title{
Gestão social e cidadania deliberativa: a experiência de Ilha Comprida - São Paulo
}

\author{
Social management and deliberative citizenship: the experience of Ilha Comprida - São \\ Paulo
}

\author{
Edson Sadao lizuka ${ }^{1}$ \\ Sylmara Lopes Francelino Gonçalves-Dias ${ }^{2}$ \\ Pedro Aguerre ${ }^{3}$
}

\section{Resumo}

Este artigo tem por objetivo discutir a atuação de diferentes atores na gestão social, tendo como foco o processo de cidadania deliberativa. Especificamente, pretende-se analisar a construção do Programa de extração de samambaia silvestre que ocorreu no município de llha Comprida. O caso em destaque ocorreu no Vale do Ribeira, território de cidadania localizado no Estado de São Paulo. Para o alcance dos objetivos propostos, utilizou-se como metodologia de pesquisa a história oral. Foram realizadas onze entrevistas pessoais com gestores públicos, técnicos municipais, estadual e federal e, principalmente, membros da comunidade local. Os dados, informações e as entrevistas foram sistematizados por meio de estudo de caso. Os resultados da pesquisa evidenciaram a importância da combinação dos conhecimentos tácitos, técnicos e científicos na construção de uma experiência inovadora e relevante neste território da cidadania. Além disso, foi possível concluir que o fluxo de ações presentes no processo decisório é permeado por diversos fatos, diálogos e eventos inesperados e não lineares que são, na maior parte das vezes, ignorados por boa parte da literatura administrativa tradicional; mas que, por outro lado, estão presentes ao que alguns pesquisadores denominam de cidadania deliberativa (HABERMAS, 2003 e TENÓRIO, 2005). Sendo assim, o estudo contribui para a compreensão de limitações e possibilidades da gestão social tendo por referência os olhares dos distintos atores, indicando que o processo de cidadania deliberativa pode se constituir em uma estratégia eficaz para o desenvolvimento local contextualizado no território.

Palavras-chaves: Gestão social. Território da cidadania. Capital social. Processo decisório. Cidadania deliberativa.

Artigo submetido em 18 de março de 2011 e aceito para publicação em 04 de agosto de 2011.

1 Doutor em Administração Publica e Governo pela FGV-EAESP; Professor do Departamento de Administração da Pontifícia Universidade Católica de São Paulo; Professor do Programa de Mestrado Profissional em Administração do Centro Universitário FECAP. Endereço: Av. da Liberdade, 532, Liberdade, CEP 01502-001, São Paulo - SP, Brasil. E-mail: edsonsadao@gmail.com

2 Doutora em Administração pela FGV-EAESP; Doutora em Ciência Ambiental pelo Programa de Ciência Ambiental da Universidade de São Paulo; Professora do Programa de Estudos Pós-Graduados em Administração da Pontifícia Universidade Católica de São Paulo. Endereço: Rua Monte Alegre, 984 - sala 121, Perdizes, CEP 05014-901, São Paulo - SP, Brasil. E-mail: sylmaraldias@gmail.com

${ }^{3}$ Doutor em Ciências Sociais pela Pontifícia Universidade Católica de São Paulo; Professor do Departamento de Administração da Pontifícia Universidade Católica de São Paulo. Endereço: Rua Monte Alegre, 984 - sala 121, Perdizes, CEP 05014-901, São Paulo SP, Brasil. E-mail: pedroaguerre@uol.com.br 


\begin{abstract}
This paper addresses the role of different actors in social management, focusing on the deliberative process of citizenship. Specifically, we intend to analyze the construction of the program to extract wild fern that occurred in the city of Ilha Comprida. The case in point occurred in the Vale do Ribeira, located in the territory of citizenship in São Paulo. To achieve the goals of the study, the research methodology used was oral history. Eleven interviews were conducted with public managers, municipal, state and federal technicians, and especially members of the local community. The data, information and interviews were systematized as a case study. The survey results showed the importance of a combination of tacit knowledge, technical and scientific experience in the construction of an innovative and relevant experience in this area of citizenship. In addition, it was concluded that the flow of present actions in the decision making process is permeated by several facts, dialogues and unexpected events that are nonlinear and in most cases, ignored by much of the traditional management literature. However, on the other hand, there is the presence of what some researchers call deliberative citizenship (Habermas 2003 and Tenório, 2005). Thus, the study contributes to the understanding of limitations and possibilities of social management with reference to the views of the different actors, indicating that the deliberative process of citizenship can constitute an effective strategy for contextualized local development within the territory.
\end{abstract}

Keywords: Social management. Territory of citizenship. Social capital. Decision-making process. Deliberative citizenship.

\title{
Introdução
}

A gestão social é um conceito em construção. Contudo, parece haver uma convergência entre alguns teóricos sobre a necessidade de um processo de gestão que seja dialógico e transparente, no qual as pessoas se comunicam livremente em busca de consensos Abramovay (2006), Dowbor (1999), Fischer (2002), Fischer e Melo (2006), França Filho (2008), Tenório (2008a, 2008b), Na medida em que a gestão social se encontra em debate, os esforços no sentido de aperfeiçoamento da sua compreensão teórica e empírica são legítimos e relevantes. Em boa parte da literatura nesta temática os autores têm feito o uso do referencial habermasiano, destacando-se a Teoria da Ação Comunicativa de Habermas (1987a, 1987b, 1989) e a análise das esferas da vida, pública e privada e, neste contexto, a cidadania deliberativa (HABERMAS, 2003).

Para efeitos deste artigo, cidadania deliberativa "significa que a legitimidade das decisões políticas deve ter origem em processos de discussão, orientados pelos princípios da inclusão, do pluralismo, da igualdade participativa, da autonomia e do bem comum" (TENÓRIO, 2005, p. 105). De fato, a construção de uma experiência num determinado território é permeada por diversos fatos, diálogos e eventos inesperados e não lineares que são, na maior parte das vezes, ignorados por boa parte da literatura administrativa tradicional.

De outro lado, é possível verificar um esforço de pesquisadores em demonstrar as diferenças entre o que pode ser considerado uma gestão tradicional ou estratégica de Tenório (2005 e 2010) racional e a gestão social participativa e, muitas vezes, não linear. Desta forma, este artigo busca contemplar a forma de atuação de diferentes atores locais na gestão social de um território, tendo como foco a cidadania deliberativa. Atores locais são todos aqueles agentes que no campo político, econômico, social e cultural são portadores e fomentadores das potencialidades locais (AROCENA, 1988 apud TENÓRIO, 2004, p. 2). Esta ideia corrobora com a indicação de Abramovay (2000) que destaca o desafio de considerar as populações locais protagonistas na construção de seus próprios territórios.

Optou-se por observar e analisar o fluxo de ações, no qual se encontram as decisões e o processo decisório, permitindo perceber fatores impulsionadores e restritivos que influenciam a escolha de uma ação ou de um processo em detrimento de outras alternativas. Nesse sentido, as questões de pesquisa que guiaram a 
construção deste artigo foram as seguintes: qual é a relevância dos processos decisórios na gestão social em determinado território? Como relacionar a participação dos diferentes atores locais sob a perspectiva da gestão social e da cidadania deliberativa?

Especificamente, pretendeu-se analisar a participação de diferentes atores na construção do Programa de extração de samambaia silvestre que ocorreu no município de Ilha Comprida, sob a ótica do processo decisório e da cidadania deliberativa. $\mathrm{O}$ caso em destaque se refere ao Vale do Ribeira, território de cidadania localizado no estado de São Paulo. Os extratores de samambaia silvestre deste pequeno município se encontravam em situação de ilegalidade devido às exigências da legislação ambiental do estado de São Paulo. No entanto, com a articulação de atores locais em torno do projeto de legalização e formação da associação dos extratores, esta atividade passou a ser reconhecida e legitimada pelas diferentes instâncias do poder público e pela comunidade local, caracterizando-se como uma prática inovadora em gestão social neste território.

Para cumprir a proposta deste artigo, optou-se por uma abordagem exploratória de pesquisa descritivoqualitativa. Para tal, utilizou-se a história oral de Berg (2004), Cassab (2003) e Verena (2004) como método de investigação e organizaram-se os dados, as informações e as entrevistas por meio de estudo de caso de Eisenhardt (1989) e Yin (2005). Ademais, essa forma de investigação permitiu uma análise sobre a participação dos diferentes atores no contexto da gestão social, assim como da cidadania deliberativa. Todas estas temáticas foram contextualizadas no processo de construção de um território.

Consequentemente o presente artigo fortalece a reflexão sobre o território que, segundo Abramovay (2000), é "mais que uma simples base física para as relações entre indivíduos e empresas, possui um tecido social, uma organização complexa feita por laços que vão muito além de seus atributos naturais". Portanto, o estudo de caso dos Extratores de Samambaia Silvestre de Ilha Comprida é uma contribuição para o fortalecimento do conceito e práticas inovadoras referentes à gestão territorial, conforme as diretrizes do Ministério do Desenvolvimento Social (MDS, 2010). Igualmente, o caso em tela é relevante para o entendimento da formatação de relações institucionais no exercício da cidadania deliberativa e que estimulam o dinamismo territorial. Para cumprir as proposições deste artigo, ele está organizado da seguinte forma: introdução da situação problema, apresentação das principais linhas teóricas sobre gestão social, território da cidadania e processo decisório. A seguir apresentam-se os procedimentos metodológicos, o estudo de caso da Extração da Samambaia Silvestre e, finalmente, as conclusões.

\section{Gestão Social e Territórios de Cidadania}

Os debates sobre gestão social no Brasil têm o seu início a partir dos primeiros anos da década de 1990 e naquele momento era um conceito restrito às organizações do chamado terceiro setor. As inquietações dos pesquisadores levavam a buscar um tipo de gestão que contemplasse a eficiência não só no planejamento como também na implantação de políticas sociais e na gestão de programas sociais (TENÓRIO, 2009).

Ao final da década de 1990 houve uma ampliação no escopo da gestão social, não mais se restringindo às organizações sem fins lucrativos. Afinal, gestão social, não é mais apenas um setor, é uma dimensão humana do próprio desenvolvimento que envolve o empresário, o pesquisador e o ativista dos movimentos sociais. Constitui-se de uma dimensão de todas as outras atividades, além de uma forma de fazer indústria, uma forma de pensar desenvolvimento urbano, uma forma de tratar dos rios, uma forma de organizar o comércio (DOWBOR, 1999).

Atualmente, pensar em gestão social significa preocupar-se com as novas formas participativas de elaboração do orçamento, com o imposto de renda negativo (renda mínima), com novas formas de representação política e com o novo potencial de comunicação (DOWBOR, 1999). Tal como descreveu 
Tenório (2009, p. 2): “[...] uma gestão ampliada na qual o processo decisório seria vinculante ao diálogo consciente, procedimental, por meios dos diferentes atores da sociedade, sob a perspectiva de sujeitos em ação". E para reforçar a dissociação com o terceiro setor e projetos sociais com a gestão social, o mesmo autor afirma tratar-se de "processo gerencial dialógico no qual a autoridade decisória é compartilhada entre os participantes da ação (ação que possa ocorrer em qualquer tipo de sistema social - público, privado ou de organizações não governamentais".

A gestão social ainda faz uma contraposição à chamada gestão estratégica, aquela hegemônica no ensino, na pesquisa e prática da Administração (TENÓRIO, 2009). Esta questão também foi evidenciada por Dowbor (1999) ao ressaltar que, enquanto as áreas produtivas dispõem de um sólido acúmulo teórico sobre a sua gestão - taylorismo, fordismo, toyotismo, gestão da qualidade total, entre outros - a área social não dispõe de paradigmas de gestão correspondentes, e fica oscilando entre burocratismos estatais ultrapassados e privatizações desastrosas.

Ademais, atuar na área social é diferente e necessita respostas específicas. A definição de gestão estratégica, conforme apresentou Tenório (2005, p. 4): "é um processo de gestão que prima pela competição, em que o outro, concorrente, deve ser excluído e o lucro é o seu motivo". A gestão social, por sua vez, é uma forma de gestão que valoriza a concordância, em que o outro deve ser incluído e a solidariedade a sua motivação. Além disso, a gestão social caracteriza-se pelo seu caráter coletivo, enquanto a gestão estratégica, pelo caráter individual, ou seja, baseado no monólogo e no indivíduo (TENÓRIO, 2005).

Ao mesmo tempo em que ocorrem discussões e debates acerca da gestão social, verifica-se que o setor público brasileiro tem buscado novas alternativas para contemplar as diferentes demandas locais contextualizadas em territórios. Territórios, nesta abordagem, "não se definem por limites físicos e sim pela maneira como se produz, em seu interior, a interação social. Desta forma, a abordagem territorial exige a análise institucional em torno da qual se organiza a interação social localizada (ABRAMOVAY, 2006). Neste contexto, em fevereiro de 2008, o governo federal brasileiro lançou um programa denominado Territórios da Cidadania ${ }^{4}$. Tal iniciativa emergiu na medida em que diversos desafios e oportunidades não estavam delimitados pela divisão geopolítica tradicional, mas sim pelos territórios constituídos por conjuntos de municípios de mesmas características econômicas, ambientais, de identidade e coesão social, cultural e geográfica (MDS, 2010).

Sendo assim, pensar nos territórios tem permitido um conhecimento mais nítido sobre a realidade dos grupos sociais, das atividades econômicas, assim como das instituições de cada localidade. O reconhecimento dessas características distintivas entre os territórios e que vieram sendo construídas ao longo de décadas, tem facilitado o planejamento de ações governamentais para o desenvolvimento tais regiões.

Pensar a gestão do território requer o envolvimento de diversas dimensões: econômica; social; cultural; ambiental e físico-territorial; político-institucional; e científico-tecnológica. Implica considerar os diferentes padrões de inter-relacionamento ativo dos diversos atores da sociedade (ABRAMOVAY, 2006 ; TENÓRIO, 2008). Nesse sentido importa, necessariamente, uma profunda transformação das relações sociais - não apenas dos processos técnicos de produção - mas também incluída a preservação ambiental, já que a incorporação dessa dimensão às estratégias, programas e projetos de desenvolvimento tem como objetivo assegurar melhores condições materiais e a sustentabilidade da sociedade, segundo as suas condições e vocações. (DOWBOR, 1999, 2006; TENÓRIO, 2004).

${ }^{4}$ Os objetivos do Programa Territórios da Cidadania são os seguintes: promover o desenvolvimento econômico e universalizar programas básicos de cidadania por meio de uma estratégia de desenvolvimento territorial sustentável, conforme apresentado no Portal da Cidadania. (MDS, 2010). Neste contexto, reconhece-se a necessidade de articulação entre o Governo Federal, os estados e municípios na construção dessa estratégia de gestão. 
Os processos de desenvolvimento local implicam esforços articulados de atores estatais, da sociedade civil e do capital, dispostos a levar adiante projetos que surjam da negociação de interesses, inclusive divergentes e em conflito. Neste contexto, emerge a cidadania deliberativa como uma categoria de análise apropriada, pois a busca por alternativas de solução às demandas locais ocorre por meio do efetivo exercício de direitos e deveres dos atores em seus territórios. Ou seja, num nível macro, no qual os desafios se impõem para as diferentes esferas públicas e privadas, a cidadania deliberativa se apresenta como uma ótica de pesquisa coerente com as práticas fomentadas - articulação entre os diferentes níveis governamentais, assim como a integração das diferentes políticas públicas; bem como a busca por uma interlocução com os atores da sociedade civil e mercado - nos diferentes territórios da cidadania. No nível micro, pode-se observar o processo gerencial deliberativo no qual os atores participam na construção de soluções que atendam às demandas que se apresentam como relevantes para esses sujeitos (TENÓRIO, 2005).

De fato, parece haver um diálogo entre a cidadania deliberativa, o processo gerencial deliberativo com a gestão social. De maneira semelhante, a participação de diferentes atores na busca por soluções para as demandas sociais, econômicas, culturais, ambientais, entre outras, nos diversos territórios, possibilita uma análise por meio da aproximação da corrente teórica administrativa que trata do processo decisório, assunto que será abordado a seguir.

\section{O Processo Decisório e o Fluxo de Ações}

Na literatura administrativa, Mintzberg (1978) foi um dos autores que se utilizou da noção do fluxo de ações para discorrer sobre a formação da estratégia numa organização. Para ele, quando uma sequência de decisões exibe uma consistência ao longo do tempo, a estratégia será considerada como realizada. Contudo, a noção que se utiliza neste artigo refere-se, a tornar-se partícipe ao pesquisar no cotidiano, conforme argumentou Spink (2007, p. 1): "fazemos parte do fluxo de ações; somos parte dessa comunidade e compartilhamos de normas e expectativas que nos permitem pressupor uma compreensão compartilhada dessas interações." $E$ ainda conforme Spink (1989, p. 2), “[...] abrindo e fechando portas para abrir e fechar opções e acessos, permitindo que certos fluxos continuem e fazendo com que outros parem". Isto requer uma contextualização cultural do processo decisório de maneira que, além da abertura para a participação dos diversos atores, esse processo possibilite um fluxo de informações em todos os sentidos de Rattner (2005) e Spink (2007).

Entretanto, as teorias clássicas em processo decisório, especificamente as que têm as suas bases na escola neoclássica da economia, pressupõem um caminho linear e centrado no indivíduo, concebido como o homo economicus. Nessa abordagem, existiria a possibilidade de reconhecer um problema ou uma oportunidade, levantar todas as informações pertinentes, elencar alternativas, selecionar a melhor alternativa, a partir da qual se trabalharia a implantação, passando-se para a mensuração dos resultados e as devidas correções e ajustes. A decisão, sob essa ótica, tem sua importância por maximizar a curva de utilidade de cada indivíduo, por meio de ótimas escolhas, calculadas a partir da seleção de variáveis presentes em cestas de alternativas conhecidas previamente pelos indivíduos.

O pressuposto teórico, portanto, é de que os seres humanos são guiados por interesses homogêneos e bemdefinidos, num processo decisório em etapas claras e previamente estabelecido. Trata-se de uma visão simplificadora do ser humano e do ambiente, pois os assumem como homogêneos, sem diversidade de interesses, guiados por uma única razão e não sujeito às influências externas. Além da crítica feita à concepção humana que sustenta essa linha teórica, diversas outras críticas foram apresentadas pela literatura: existe assimetria no acesso e uso das informações e, além disso, é improvável ter acesso a todas as informações; questiona-se a capacidade de escolha da "melhor" alternativa, feita por um único indivíduo, sem qualquer influência de emoções e intuições (LEITÃO,1993, 1996), (MOTTA,1988), (SIMON, 1959, 1965, 1978) e (VERGARA, 1993). 
Foi em busca de uma explicação menos abstrata e mais condizente com a realidade que Herbert Simon (1965) formulou a teoria da racionalidade limitada. Por essa linha teórica, a tomada de decisões ficaria delimitada ao ambiente organizacional, e a decisão seria por uma alternativa satisfatória. Formulou-se outra concepção de ser humano: o homem administrativo. As limitações cognitivas foram evidenciadas, ou seja, avançou-se no sentido de reconhecer um ser humano que possui diferentes capacidades para acessar, compreender e utilizar as informações disponíveis. Se, por um lado, as limitações humanas foram reconhecidas, por outro se manteve o princípio de que as escolhas são tão racionais quanto possíveis.

Há muitos projetos e programas, delineados nas instâncias estaduais e federais, que influenciam os governos locais, mas que são incapazes de criar caminhos que permitam um mínimo de competência dialógica. As regras estabelecidas e, também, a falta de reconhecimento dos múltiplos saberes geram ciclos de produção e reprodução da desigualdade e da exclusão social. São exemplos disso os editais publicados pelas Secretarias e Ministérios, nas mais diversas áreas e setores, em que são definidos parâmetros e regras que nem sempre são compatíveis com a diversidade local, demarcados por distintas características políticas, econômicas, culturais, geográficas, entre outras. Estas delimitações, muitas vezes, submetem e constrangem os gestores municipais a uma "adequação" dos seus projetos em função do que é disponibilizado pelas outras instâncias governamentais.

A perspectiva negociada ao longo do processo de definição e implantação das políticas públicas foi descrita pelos teóricos, sobretudo da ciência política, adeptos ao processo decisório baseado no incrementalismo, sendo um dos seus principais teóricos Charles Lindblom (1958). Sob essa abordagem teórica, existe a busca de soluções para os problemas mais imediatos e prementes por meio da análise da micropolítica e das experiências anteriores, o que se opõe, em alguma medida, ao método racional compreensivo em que o enfoque recai sobre a macropolítica. Pressupõe-se uma interação entre os decisores, os agentes (burocratas) e demais pessoas envolvidas nas políticas públicas, resultando num jogo político, porque envolve interação, conflito e barganha o tempo todo. Nesse contexto, os conflitos são considerados como algo inerente ao processo, ao contrário da abordagem racional em que se considera o conflito como disfuncional e que, portanto, deveria ser coibido.

Assim como ocorre na linha teórica do incrementalismo, o sensemaking reconheceu a importância das experiências anteriores no processo de decisão, sendo que a compreensão dessas experiências só é possível depois de ocorrido o fato, ou seja, de forma retrospectiva (WEICK, 1995). Trata-se, portanto, de uma construção contínua de sentidos, num processo em que não se pode definir um "começo, meio e fimm". A ênfase, contudo, seria na negociação de sentidos, ou seja, não limitado aos aspectos políticos e institucionais que foram destacados na linha teórica vinculada ao incrementalismo. Numa linha semelhante, Mintzberg (1985) formulou a concepção das "estratégias emergentes", na qual reconheceu que apenas durante o processo de execução das tarefas é que determinadas estratégias surgem como relevantes, não sendo possível estabelecê-las de forma deliberada.

De forma distinta ao incrementalismo e ao sensemaking e às teorias decisórias lineares, o modelo lata do lixo (garbage can model) de Cohen, March e Olsen (1972) busca demonstrar um processo decisório como uma "anarquia organizada", ou seja, um processo randômico, em que ocorreriam encontros casuais, em determinadas circunstâncias, de escolhas, problemas, soluções e decisores. Por essa abordagem teórica, demonstraram-se algumas situações decisórias em que as "soluções buscavam problemas". Diversas soluções seriam acumuladas na "lata do lixo" e, em algum momento, uma delas seria resgatada, segundo o problema verificado. $\mathrm{O}$ aspecto temporal, portanto, demonstrou-se relevante no modelo da lata do lixo.

A literatura estrangeira sobre a inovação governamental tende a focalizar um debate entre processos planejados e os não planejados baseados no groping along (BEHN, 1988). Numa pesquisa feita com experiências inovadoras, premiadas pela Harvard University - Kennedy School of Government, entre $1991 \mathrm{e}$ 1994, o pesquisador canadense Borins (2001) constatou que 59\% dos projetos e programas inovadores em âmbito governamental foram conduzidos de maneira planejada, enquanto $30 \%$ poderiam ser caracterizados 
pelo groping along e em 7\% dos casos utilizou-se sistematicamente o planejamento estratégico. Além disso, Borins (2001) destacou a importância prática do small wins (comemorar as "pequenas vitórias") para o início dos projetos e programas.

O autor concluiu seu estudo indicando que os projetos planejados estão mais relacionados aos altos investimentos, à coordenação compartilhada por diversas organizações, a programas baseadas em teorias; em contraste, o groping along esteve presente nos casos em que não havia recursos suficientes, em situações de não coordenação intra e interorganizacional, e sem uma referência teórica. Num estudo similar, Golden (1990) concluiu que os projetos governamentais inovadores em programas de assistência social basearam-se no groping along e não em planejamentos. Essas pesquisas parecem trazer à tona um debate sobre a linearidade (planejamento) e não linearidade (groping along) nos processos de construção das políticas públicas.

Há outras teorias e modelos sobre o processo decisório, além dos já mencionados, tais como a Teoria dos Jogos, Coalizões Políticas, Agenda de Políticas Públicas, Lógica Fuzzy, Análise Custo- Benefício, Árvores de Decisão, Modelos de Multiatributos, entre outros ${ }^{5}$. Além disso, encontram-se literaturas que buscam analisar a influência da cultura, do contexto, das redes e das complexas relações entre atores e até mesmo das religiões no processo decisório (MORÇÖL, 2007). Este artigo limitou-se ao uso das principais teorias no âmbito da formulação de uma política pública e, portanto, não se pretendeu esgotar as abordagens teóricas sobre o processo decisório. Apenas utilizou-se esta base teórica como um meio de análise da participação dos diferentes atores durante a construção do projeto em um dos municípios do território da cidadania do Vale do Ribeira-SP. A seguir, apresenta-se a estratégia metodológica para construção das evidências do caso da Extração da Samambaia Silvestre em Ilha Comprida, no Território da Cidadania situado na região sudeste São Paulo.

\section{Procedimentos Metodológicos}

Para o desenvolvimento deste estudo, optou-se por uma abordagem exploratória de pesquisa descritivoqualitativa, na medida em que se trata de uma temática pouco investigada e sobre a qual é necessário um aperfeiçoamento na questão de pesquisa. Assim sendo, exigiu-se um esforço inicial na compreensão do território a ser investigado que tende a ser difuso e multifacetado. Além disso, a pesquisa qualitativa apresentou-se como a mais adequada à problemática de pesquisa e a que permitiu um avanço no entendimento da participação dos diferentes atores no contexto de uma gestão social no território, assim como da cidadania deliberativa.

Como método de pesquisa, utilizou-se a história oral de (BERG, 2004), (CASSAB, 2003) e (VERENA, 2004). A história oral baseia-se em dois paradigmas: a ideia do indivíduo entendido como valor e o modo de pensar hermenêutico, no qual se procura encontrar sentido que sirva como estratégia totalizadora para a explicação das experiências. Tal método tem grande proximidade com temas como memória, biografia e narrativa oral. Consiste na realização de entrevistas gravadas com pessoas que participaram de ou que testemunharam acontecimentos e conjunturas do passado, e também do presente. Ao utilizar esse método, o

\footnotetext{
5 Os pesquisadores Neyland e Surridge (2003), utilizando a ferramenta de busca acadêmica Jstor, verificaram 86 abordagens distintas para o processo decisório. No Brasil, os autores Hoppen e Löbler (2004) fizeram uma pesquisa nos principais periódicos em administração no país, entre 1993 e 2002, e verificaram que tal assunto tem se apresentado em diferentes campos do conhecimento, com abordagens desde as matemáticas e econométricas até as sociológicas e psicológicas, implicando, assim, uma grande heterogeneidade de metodologias utilizadas para a análise. Para as abordagens "Análise Custo-benefício", "Árvores de Decisão" e "Modelos Multicritérios", ver Carvalho (2005) e Morçöl (2007).
} 
pesquisador tem o acesso a informações e pistas sobre aspectos de difícil apreensão por outros caminhos investigativos, as experiências pessoais e impressões particulares (VERENA, 2004).

Este artigo é fruto de pesquisa desenvolvida em duas etapas. A primeira, de 2004 a 2008, quando se realizou revisão bibliográfica, definição de metodologia, coleta e análise preliminar dos dados. A segunda etapa aconteceu entre 2010 e 2011, quando novas reflexões foram empreendidas. Isto exigiu retorno à literatura e ao campo, além de provocar debates dos autores em eventos e fóruns acadêmicos.

$\mathrm{Na}$ fase inicial, procedeu-se à busca e análise dos trinta e quatro projetos e programas desenvolvidos em pequenos municípios brasileiros, premiados pelo Programa Gestão Pública e Cidadania da FGV-EAESP (Fundação Getulio Vargas - Escola de Administração de Empresas de São Paulo) entre os anos de 1996 e 2005. Foi selecionada a experiência inovadora da Extração da Samambaia Silvestre em Ilha Comprida-SP, levando-se em consideração os seguintes aspectos: o grau de complexidade do projeto ou programa, os fluxos de ações, a localização geográfica no território de cidadania do Vale do Ribeira. O Vale do Ribeira mostrava-se um universo de pesquisa adequado, possibilitando o reconhecimento das potencialidades e fragilidades da comunidade local em regiões de baixo dinamismo econômico e extrema pobreza.

Apesar de não haver um lócus mais ou menos adequado para a gestão social, o fato é que os Territórios da Cidadania apresentam-se como um campo empírico de análise relevante. Apesar de tais territórios apresentarem desafios e potencialidades em comum, são também permeados por diversos interesses e percepções, nos quais diferentes atores têm buscado alternativas para a sua sobrevivência, além de melhorias sociais, econômicas e ambientais. Por outro lado, é preciso considerar que os problemas vividos nos territórios dificilmente podem ser equacionados sem que exista, em maior ou menor grau, algum tipo de debate entre os sujeitos, ou seja, a existência efetiva de diálogos entre os mesmos.

Assim, organizaram-se os dados, as informações e as entrevistas por meio de estudo de caso de Lakatos e Marconi (2001), Yin (2005) e Vergara (2005) num contexto de uma pesquisa exploratória. Entre as diversas técnicas de pesquisa qualitativa, o método do estudo de caso constituiu-se na abordagem mais adequada, na medida em que se pretendia uma análise aprofundada sobre atores locais, processo decisório e cidadania deliberativa, buscando aprimorar o entendimento da gestão social em um território, o que implicou conhecer o contexto específico de manifestação do fenômeno (LAKATOS e MARCONI, 2001), (YIN, 2005) e (VERGARA, 2005).

Além disso, o método do estudo de caso permitiu a visão geral, buscando relacionar as partes com o todo, a partir da realização de observações amplas, e utilizando várias fontes de coleta de dados (GONDIM et al., 2005). As múltiplas fontes de coleta de evidências foram úteis para diminuir os vieses do pesquisador e, além disso, permitiram a triangulação (VIEIRA, 2004) o que possibilitou, em geral, mais qualidade ao trabalho de pesquisa (LAKATOS e MARCONI, 2001), (YIN, 2005) e (VERGARA, 2005). Os meios utilizados para a construção e análise do caso dividiram-se em duas partes principais: (i) levantamentos de documentos, tais como: atas de reunião, fotos, vídeos, recortes de jornais, revistas, material institucional das prefeituras; (ii) entrevistas com atores.

A partir da metodologia da história oral, diferentes atores foram ouvidos, e as suas visões de mundo foram registradas. No quadro 1 apresenta-se a caracterização dos onze atores entrevistados, resguardadas suas identidades: 
Quadro 1

Caracterização dos atores entrevistados

\begin{tabular}{|c|c|c|c|}
\hline ATOR & Grupo & Código & Característica \\
\hline \multirow{4}{*}{$\begin{array}{l}\text { Comunidade } \\
\text { local }\end{array}$} & \multirow{4}{*}{$\begin{array}{l}\text { Extratores de } \\
\text { samambaia }\end{array}$} & Extrator 1 & \multirow{4}{*}{$\begin{array}{l}\text { Extratores de Samambaia Silvestre. Conviveram com a } \\
\text { ilegalidade da atividade da extração da samambaia e } \\
\text { participaram dos debates e discussões sobre as mudanças } \\
\text { necessárias, tanto em ambientes informais (reuniões } \\
\text { entre famílias), como também nos fóruns promovidos } \\
\text { pela prefeitura. }\end{array}$} \\
\hline & & Extrator 2 & \\
\hline & & Extrator 3 & \\
\hline & & Extrator 4 & \\
\hline \multirow[t]{2}{*}{$\begin{array}{l}\text { Poder } \\
\text { Público local } \\
\text { Executivo }\end{array}$} & $\begin{array}{l}\text { Ex-prefeito do } \\
\text { município }\end{array}$ & Executivo 1 & $\begin{array}{l}\text { Ex-prefeito de Ilha Comprida. Era chefe do executivo } \\
\text { municipal na época em que o programa foi criado e } \\
\text { implantado. Foi um dos atores mais atuantes em todo o } \\
\text { processo. }\end{array}$ \\
\hline & $\begin{array}{l}\text { Vice-prefeito } \\
\text { do município }\end{array}$ & Executivo 2 & $\begin{array}{l}\text { Vice-prefeito de Ilha Comprida. Em sua juventude, } \\
\text { trabalhou como extrator de samambaia silvestre. Muito } \\
\text { respeitado pela comunidade local devido ao seu histórico } \\
\text { pessoal, contribuiu, especialmente, na sensibilização de } \\
\text { outros atores governamentais. }\end{array}$ \\
\hline \multirow[t]{3}{*}{$\begin{array}{l}\text { Órgão } \\
\text { técnico } \\
\text { municipal }\end{array}$} & \multirow{2}{*}{$\begin{array}{l}\text { Técnicos de } \\
\text { órgão } \\
\text { municipal do } \\
\text { meio } \\
\text { ambiente }\end{array}$} & $\begin{array}{l}\text { Técnico municipal do } \\
\text { meio ambiente-1 }\end{array}$ & \multirow{2}{*}{$\begin{array}{l}\text { Membros da Secretaria Municipal de Meio Ambiente de } \\
\text { llha Comprida. Participaram desde os primórdios do } \\
\text { programa. }\end{array}$} \\
\hline & & $\begin{array}{l}\text { Técnico municipal do } \\
\text { meio ambiente- } 2\end{array}$ & \\
\hline & $\begin{array}{l}\text { Técnico de } \\
\text { órgão } \\
\text { municipal } \\
\text { para gestão } \\
\text { do território }\end{array}$ & $\begin{array}{l}\text { Técnico municipal } \\
\text { para gestão do } \\
\text { território }\end{array}$ & $\begin{array}{l}\text { Funcionário da prefeitura de Ilha Comprida e o principal } \\
\text { responsável pela parte operacional do programa. } \\
\text { Participou dos debates iniciais e mantém um contato } \\
\text { estreito com os extratores e o poder público local. }\end{array}$ \\
\hline $\begin{array}{l}\text { Órgão } \\
\text { técnico } \\
\text { estadual }\end{array}$ & $\begin{array}{l}\text { Técnico de } \\
\text { órgão } \\
\text { estadual de } \\
\text { recursos } \\
\text { naturais }\end{array}$ & $\begin{array}{l}\text { Técnico estadual de } \\
\text { recursos naturais }\end{array}$ & $\begin{array}{l}\text { Profissional do Departamento Estadual de Proteção de } \\
\text { Recursos Naturais (DEPRN). Foi um dos interlocutores com } \\
\text { o poder público estadual no processo de legalização da } \\
\text { atividade extrativista de samambaia silvestre. }\end{array}$ \\
\hline $\begin{array}{l}\text { Órgão } \\
\text { técnico } \\
\text { federal }\end{array}$ & $\begin{array}{l}\text { Representante } \\
\text { do IBAMA }\end{array}$ & $\begin{array}{l}\text { Representante do } \\
\text { IBAMA }\end{array}$ & $\begin{array}{l}\text { Representante do IBAMA na região do Vale do Ribeira na } \\
\text { oportunidade em que foi desenvolvida a iniciativa em llha } \\
\text { Comprida. }\end{array}$ \\
\hline
\end{tabular}

Fonte: dados da pesquisa. 
Existe o pressuposto do reconhecimento dos elementos diferentes e de igualdade de cada sujeito, exigindo-se uma postura de respeito e importância a cada indivíduo. A pessoa que narra sua história de vida ou oferece um depoimento não se constitui, ela própria, no objeto de estudo, mas sim seus relatos, sua realidade vivida. Ela apresenta os eventos vistos sob seu prisma, o que possibilitou conhecer as relações sociais e as dinâmicas que se inserem no objeto de estudo. Assim, o que se buscou foram as versões dos fatos, tendo como princípio a existência de lacunas espaciais e temporais e, além disso, aceitam-se as subjetividades implícitas no relato, tanto por parte do narrador, como também pelo pesquisador (CASSAB, 2003) e (VERENA, 2004).

Com o decorrer das entrevistas, abriu-se a possibilidade de alterações na captação de dados, pois a reflexão e a análise se fizeram presentes concomitantemente às conversas; determinadas dúvidas foram dirimidas, ao mesmo tempo em que novos questionamentos surgiram, configurando-se, assim, num movimento dialógico. Durante o processo de entrevistas, descobrir indícios do que até então não tinha sido percebido e, para que esse intuito fosse cumprido, além de estar atento ao que o narrador dizia, foi preciso prestar atenção ao que também não era dito (CASSAB, 2003) e (VERENA, 2004).

No que se refere à análise de dados, foram definidas como categorias analíticas, as cinco dimensões propostas por Tenório (2004): cidadania, poder público, sociedade civil, potencial do território e o capital social. Estas dimensões pareceram apropriadas para entender os fatores impulsionadores e restritivos aos avanços sociais na realidade do caso em tela, pois emergiram e foram consolidados na análise de projetos em gestão social de 55 municípios em diferentes territórios brasileiros. A figura 1 representa tais dimensões, em sua inter-relação.

Figura 1

Dimensões de análise da gestão do território e o processo decisório

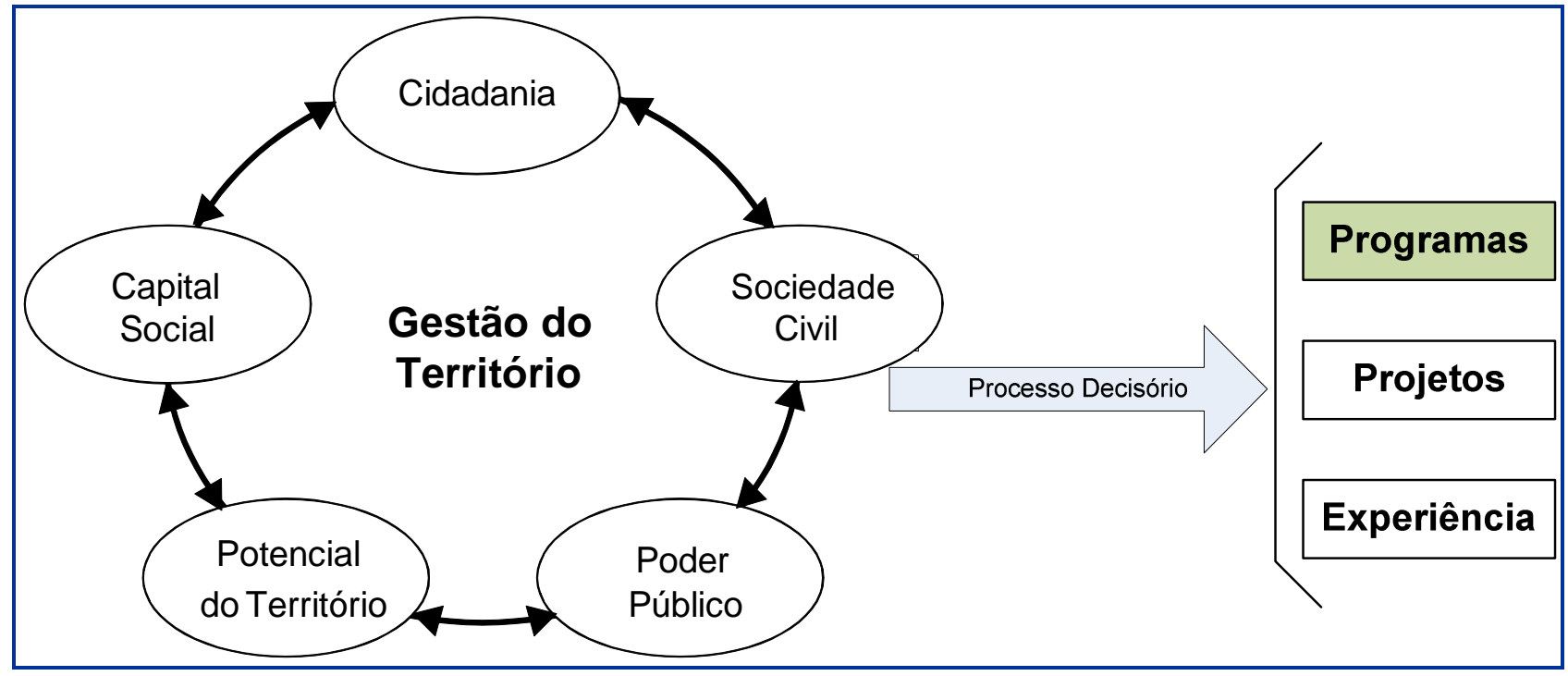

Fonte: Elaborado pelos autores a partir de Tenório (2004, p. 5-8).

Tendo como ponto de partida as cinco dimensões da pesquisa desenvolvida por Tenório (2004), é pertinente analisar o programa de Extração de Samambaia Silvestre localizado no território de cidadania do Vale do Ribeira. Quais sejam: 
i. Cidadania: em especial, refere-se ao contato, conhecimento e exercício dos direitos e deveres, participação popular, controle social do poder público (TENÓRIO, 2004);

ii. Sociedade civil, especificamente com relação à negociação entre atores, desenvolvimento sustentável, predomínio dos interesses coletivos, valorização da diversidade local, empoderamento das lideranças locais entre outros (TENÓRIO, 2004);

iii. Poder público: Esta instituição deve funcionar como articuladora e facilitadora de ações, que só terão eficácia quando representativas de um projeto de desenvolvimento apropriado pela sociedade. Num contexto participativo, o poder público pode ser considerado apenas um dos agentes envolvidos (TENÓRIO, 2005). Especialmente, governos em suas diferentes instâncias e setores, comprometimento do quadro funcional com a coisa pública, promoção da vocação econômica, entre outros;

iv. Potencial do território: A lógica do desenvolvimento local necessita fortalecer atores inscritos em seus territórios e com capacidade de iniciativa e propostas socioeconômicas que capitalizem as vocações do território e suas potencialidades locais (TENÓRIO, 2004). De que maneira se pode ampliar os valores sociais, beneficiando com isso os que ali vivem (ABRAMOVAY, 2001). É importante ainda ressaltar a importância da valorização da cultura local para afirmar direitos dos diferentes atores locais (DOWBOR, 1999). Mais especificamente, nesta dimensão devem-se avaliar quais são as vocações locais, suas características ambientais, culturais e econômicas. E ainda quais são os recursos naturais presentes na região. Há possibilidade para fortalecimento de parcerias entre os atores, entre outros;

v. Capital social: Corresponde a recursos cujo uso abre caminhos para o estabelecimento de novas relações entre os habitantes de uma determinada região (ABRAMOVAY, 2000). Conforme os trabalhos de Coleman (1990), Putnam (1993) e Putnam (1996, p. 177), capital social diz respeito a "características da organização social, como confiança, normas e sistemas, que contribuam para aumentar a eficiência da sociedade, facilitando ações coordenadas". A literatura sobre capital social distingue dois tipos fundamentais de vínculos entre os indivíduos (ABRAMOVAY, 2001), (MOYANO, 1999), (PUTNAM, 2000) e (WOOLCOCK, 1998). Por um lado estão os laços de "tipo cola": a confiança que se forma com base na identidade social dos atores, em seu sentimento comunitário de pertencer ao mesmo universo, à partilha de tradições e valores comuns. Estes laços são importantes, mas, por si só, insuficientes para permitir a mobilização de recursos capazes de estimular iniciativas inovadoras. Abramovay (2001) diz que mais que isso, tais laços podem representar o fechamento deste conjunto social sobre si próprio, ossificando as formas locais de dominação, o que vai resultar na impossibilidade de incorporar as aspirações das novas gerações e de novas demandas. Razão pela qual adquire importância outro tipo de vínculo entre os indivíduos que têm um "formato de ponte": a capacidade de um determinado grupo de ampliar o círculo de relações em que se movem os indivíduos, além daqueles que participam imediatamente de sua vida social.

Apresentados os procedimentos metodológicos adotados nesta pesquisa, parte-se para a descrição e análise de Ilha Comprida que é um município de pequeno porte que se encontra no Vale do Ribeira, conforme será apresentado a seguir.

\section{A Prática de Gestão Social e Cidadania Deliberativa na Construção da Experiência de Extração da Samambaia Silvestre em Ilha Comprida}

O Vale do Ribeira constitui um dos três Territórios da Cidadania do estado de São Paulo. Os outros são: Pontal do Paranapanema e Sudoeste Paulista. Localizado no sudeste do estado, abrange uma área de 
18.112,80 (km2) e é composto por 25 municípios $^{6}$. O território ocupa toda a região administrativa de Registro, mesmo nome do município-sede da Região, que é também o seu principal centro econômico e populacional. O Vale do Ribeira se estende também por pequenas porções das regiões administrativas vizinhas de Sorocaba (oito municípios), Santos (município de Peruíbe) e Região Metropolitana de São Paulo (Municípios de Juquitiba e São Lourenço da Serra). Faz também fronteira com o estado do Paraná, onde, contíguo, estende-se outro território da cidadania, também denominado Vale do Ribeira, em cuja área também predomina a Mata Atlântica, entre outras características comuns quanto ao perfil do povoamento e da dinâmica econômica. Na figura 2 pode-se visualizar o território de cidadania Vale do Ribeira e, em destaque, o Municípo de Ilha Comprida.

Figura 2

\section{Mapa do território Vale do Ribeira}

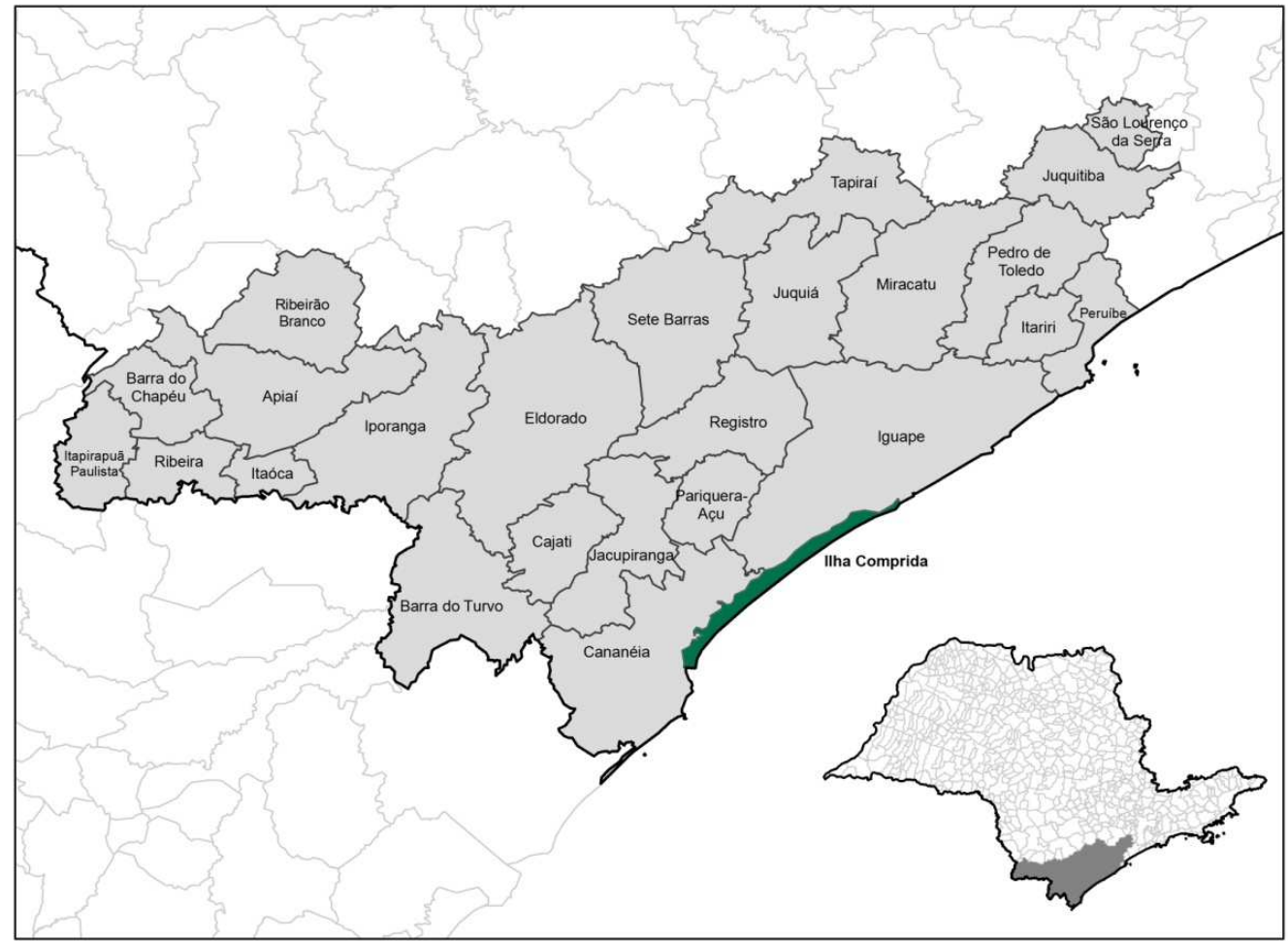

Fonte: Elaboração própria a partir de base de dados georreferenciados,

Divisão Política 2006 do IBGE. Disponível em www.ibge.gov.br.

Como se pode observar pelo mapa, o Vale do Ribeira apresenta também uma longa faixa litorânea, denominada de litoral sul paulista, onde se situa a porção territorial que veio a se constituir recentemente como o município de Ilha Comprida, onde se processou o Programa e as experiências de gestão social contextualizadas no presente artigo. A população total do território é de 431.747 habitantes, dos quais 114.949 vivem na área rural, o que corresponde a $26 \%$ do total, conforme a tabela 1 . Nos 17 menores municípios do território (aqueles dispostos na categoria 'demais municípios'), vale dizer, a população rural

${ }^{6}$ Os vinte e cinco (25) municípios do território de Cidadania do Vale do Ribeira são: Cajati, Cananéia, Iguape, Iporanga, Itaóca, Itariri, Jacupiranga, Juquiá, Juquitiba, Pariquera-Açu, Pedro de Toledo, Peruíbe, Registro, Sete Barras, Ilha Comprida, Apiaí, Barra do Chapéu, Barra do Turvo, Eldorado, Itapirapuã Paulista, Miracatu, Ribeira, Ribeirão Branco, São Lourenço da Serra e Tapiraí. 
alcança 38,7\%, o que denota o perfil tradicional das atividades econômicas da Região, de base agrícola, insinuando o baixo dinamismo efetivamente encontrado na economia e nos indicadores sociais.

A população do território observou pequeno crescimento populacional na década dos anos 2000, de 2,6\%, resultante de desempenhos díspares dos seus municípios. Em particular, destacou-se o crescimento populacional de Peruíbe (16,7\%), município litorâneo como Ilha Comprida, de forte vocação turística, que superou Registro no ranking dos mais populosos. Ilha Comprida foi o que observou a maior expansão relativa da população $(35,3 \%)$, passando de 6,5 mil para os atuais nove mil habitantes. Numa região em que a população moradora no meio rural ainda é elevada, os habitantes de Ilha Comprida habitam o núcleo urbano - embora distribuídos por diversos núcleos mais ou menos distantes do centro principal, próximos às atividades agrícolas e extrativas que constituem as principais fontes de ocupação e renda de seus habitantes.

Tabela 1

População, taxa de crescimento, distribuição rural, urbana taxa de urbanização e PIB (Produto Interno Bruto) Vale do Ribeira - municípios selecionados - 2000, 2010

\begin{tabular}{|c|c|c|c|c|c|c|c|c|}
\hline \multirow[b]{2}{*}{ Vale do Ribeira } & \multicolumn{5}{|c|}{ População } & \multirow{2}{*}{$\begin{array}{c}\text { Taxa } \\
\text { Geométrica- } \\
\text { Crescimento } \\
\text { Anual da } \\
\text { População - } \\
2000 / 2010 \\
\text { (Em \% a.a.) } \\
\end{array}$} & \multicolumn{2}{|c|}{ PIB $^{\text {(a) }}$} \\
\hline & 2000 (a) & 2010 (b) & $\begin{array}{c}\text { Variação } \\
\text { (b/a) }\end{array}$ & Rural & Urbana & & $\begin{array}{l}\text { Milhões } \\
\text { de reais }\end{array}$ & $\begin{array}{l}\text { PIB per } \\
\text { capita }\end{array}$ \\
\hline Peruíbe & 51.237 & 59.768 & 16,7 & 668 & 59.100 & 1,6 & 535,3 & $9.367,0$ \\
\hline Registro & 53.704 & 54.248 & 1,0 & 6.089 & 48.159 & 0,1 & 486,1 & $8.824,7$ \\
\hline Iguape & 27.410 & 28.828 & 5,2 & 4.144 & 24.684 & 0,5 & 220,2 & $7.245,5$ \\
\hline Juquitiba & 26.388 & 28.711 & 8,8 & 6.487 & 22.224 & 0,9 & 198,7 & $6.829,0$ \\
\hline Cajati & 29.176 & 28.367 & $-2,8$ & 7.651 & 20.716 & $-0,3$ & 422,9 & $14.587,9$ \\
\hline Apiaí & 27.153 & 25.211 & $-7,2$ & 6.974 & 18.237 & $-0,7$ & 216,7 & $8.381,0$ \\
\hline Miracatu & 22.349 & 20.574 & $-7,9$ & 9.999 & 10.575 & $-0,8$ & 144,5 & $6.101,8$ \\
\hline Ilha Comprida & 6.653 & 9.000 & 35,3 & - & 9.000 & 3,1 & 87,4 & $8.930,3$ \\
\hline $\begin{array}{l}\text { Demais } \\
\text { municípios }\end{array}$ & 187.677 & 188.381 & --- & 72.937 & 115.444 & --- & 1.389 & --- \\
\hline $\begin{array}{l}\text { TOTAL Vale do } \\
\text { Ribeira }\end{array}$ & 431.747 & 443.088 & 2,6 & 114.949 & 328.139 & --- & $3.700,8$ & -- \\
\hline
\end{tabular}

Fonte: Informações Municipais Paulistas. FSEADE.

http://www.seade.sp.gov.br/produtos/imp/

Nota: (a) Produto Interno Bruto (Em milhões de reais correntes), 2008. 
A riqueza produzida no Vale do Ribeira somou 3.700 milhões de reais (em 2008), bastante concentrada, pela ordem, nos municípios de Registro, Peruíbe e Cajati, totalizando 39\% do total. O município de Ilha Comprida responde por 2,4\% do total. Em termos per capita, na Região se destaca o município de Cajati, com R 14,6 mil. No município de Ilha Comprida este valor é de R \$ 8,9 mil, mesma faixa da maioria dos municípios da região. Cabe destacar que, no conjunto do estado de São Paulo, o produto interno bruto por habitante passa de $\mathrm{R} \$ 24$ mil, contra menos da metade no Vale do Ribeira, o que evidencia a menor pujança econômica deste agregado.

O Índice de Desenvolvimento Humano (IDH) médio deste territorio é 0,75 (MDA, 2010), uma situação que estimula a migração de parte da população economicamente ativa e jovem para outras regiões, em busca de estudo e trabalho. Mais de $60 \%$ do território Vale do Ribeira está sob algum regime de proteção, por possuir as maiores áreas contínuas de remanescentes de Mata Atlântica e por abrigar uma das maiores concentrações de cavernas calcárias do mundo. Na região, prevalece a agricultura familiar, onde se buscam alternativas de viver dos recursos naturais existentes e ao mesmo tempo proteger a variada biodiversidade local. Essa não é tarefa fácil, considerando-se que os índices de desenvolvimento humano dos municípios do Vale do Ribeira estão abaixo da média estadual, apesar de suas riquezas naturais (MDA, 2010).

Tal perfil socioeconômico tem como uma de suas características grau significativo de informalidade e pouca cobertura das estatísticas de emprego. Nessa linha, o emprego formal registrado na região como um todo soma 65.477 vínculos, resultado de um acréscimo de $31 \%$ na década (tabela 2). A expansão dos empregos na década não alterou a sua composição interna, assentada nos serviços, que absorvem quase metade dos trabalhadores. O comércio ocupa o segundo lugar, com 21,9\% ou 14,3 mil vínculos, seguido da Agricultura, com 16,3\% dos trabalhadores registrados, ou seja, 10,7 mil pessoas. Merece destaque o aumento de participação da construção civil, de $2,3 \%$ para $4,1 \%$ na década.

Tabela 2

\section{Vínculos empregatícios formais e rendimentos \\ Total de empregos formais, por setor econômico Território do Vale do Ribeira - 2000, 2009}

\begin{tabular}{|l|l|c|c|c|r|r|r|}
\hline \multirow{2}{*}{\multicolumn{2}{|c|}{ Vale do Ribeira }} & \multicolumn{6}{|c|}{ Vínculos empregatícios formais } \\
\cline { 3 - 8 } \multicolumn{2}{|l|}{} & Agropecuária & Comércio & Construção Civil & Indústria & Serviços & Total \\
\hline \multirow{2}{*}{ Total 2000} & N & 7.624 & 9.073 & 1.170 & 4.557 & 27.524 & 49.948 \\
\cline { 2 - 8 } & $(\%)$ & 15,3 & 18,2 & 2,3 & 9,1 & 55,1 & 100,0 \\
\hline \multirow{2}{*}{ Total 2009 } & N & 10.699 & 14.333 & 2.709 & 5.694 & 32.042 & 65.477 \\
\cline { 2 - 8 } & $(\%)$ & 16,3 & 21,9 & 4,1 & 8,7 & 48,9 & 100,0 \\
\hline
\end{tabular}

Fonte: Informações Municipais Paulistas. FSEADE.

http://www.seade.sp.gov.br/produtos/imp/

Os registros do sistema de informações territoriais do Ministério do Desenvolvimento Agrário assinalam a presença de 7.037 agricultores familiares, 159 famílias assentadas, 33 comunidades quilombolas e 13 terras indígenas. Trata-se de comunidades espalhadas pelo território, frequentemente mais vulneráveis socialmente, exigindo maiores esforços por parte dos formuladores de políticas públicas, como se observa no campo dos territórios da cidadania (MDA, 2010). 
Com pouco mais de nove mil habitantes, Ilha Comprida possui uma área de $188,9 \mathrm{~km}^{2}$, com uma densidade demográfica de 51 habitantes por $\mathrm{km}^{2}$, distante $214 \mathrm{~km}$ da capital de São Paulo. O nome deve-se à sua característica peculiar de ter $74 \mathrm{~km}$ de extensão e, no máximo, $4 \mathrm{~km}$ de largura em alguns pontos. Em 1987, Ilha Comprida foi declarada Área de Proteção Ambiental (APA) Estadual. O movimento pela emancipação desse município ganhou força em 1990, com um grupo de pessoas buscando melhores condições à vila. Em 27 de outubro de 1991, o plebiscito deu a vitória com 87\% dos votos à emancipação, que foi promulgada em 5 de março de 1992, data oficial da fundação do município, que foi elevado à condição de Estância Balneária em 07 de dezembro de 1994.

No passado, a base econômica de Ilha Comprida era formada pelo café, o algodão, o feijão e o milho. A partir da década de 1990, a pecuária fortaleceu-se, assim como a cana-de-açúcar, que se tornou uma das atividades principais dos pequenos agricultores. $\mathrm{O}$ extrativismo vegetal é uma atividade tradicional em Ilha Comprida. Atualmente, os setores econômicos mais relevantes são: o turismo, a pesca em pequena escala e a especulação imobiliária. O turismo é a principal atividade econômica, ficando à mercê da sazonalidade, assim como em outros municípios similares, pois, conforme descrito pelo ex-prefeito de Ilha Comprida: "a atividade econômica central dele é o turismo e, como todo município que vive de turismo, ele tem um problema de sazonalidade muito grande, então você precisa arrumar atividades econômicas para essas comunidades nos períodos que não são de veraneio".

Por outro lado, Ilha Comprida caracteriza-se por suas ricas fauna e flora, tal como lembrou o Vice-prefeito: "nós estamos numa área rodeada de mata atlântica e estamos numa das áreas lagunadas de São Paulo, estamos no meio do maior estuário de peixe e preservado ainda. O pessoal dentro do estado não viu isso ainda." E, atualmente, principalmente após a emancipação do município, Ilha Comprida tem avançado em diversas áreas, como disse o vice-prefeito, cuja opinião foi compartilhada por outros entrevistados:

[...] nós hoje temos facilidades, melhorou o atendimento com a educação, com a saúde. Só hoje nós temos uma facilidade de nossos filhos estudarem muito mais fácil. $\mathrm{O}$ atendimento da saúde está num patamar muito bom. Nós temos a saúde da família [...], por exemplo, aqui em Pedrinhas (distrito), nós temos o postinho de saúde, agentes de saúde que vão visitar os pacientes. Uma vez por mês tem médico. Dentista, nós temos uma vez por semana. Qualquer problema anormal os agentes já encaminham para frente. Então hoje a gente considera um paraíso de melhoramento que a Ilha Comprida teve após a emancipação.

A emancipação de Ilha Comprida como Município, alguns anos após a declaração da Área de Proteção Ambiental e a continuidade política foram elementos que contribuíram para que a população buscasse melhores condições de vida. Isso ajuda a compreender o contexto em que se inseriu o Programa de extração da samambaia silvestre, o qual será apresentado a seguir.

\section{A Participação de Diferentes Atores na Construção da Experiência da Extração da Samambaia Silvestre em Ilha Comprida - São Paulo}

Com o advento da Legislação Ambiental ${ }^{7}$, uma parcela da população, composta principalmente de caiçaras, passou a extrair e a vender uma espécie de planta protegida e de exploração e comercialização proibida - a

7 O Decreto no 30.817 regulamenta a Área de Proteção Ambiental da llha Comprida, criada pelo Decreto no 26.881, de 11 de março de 1987, declara essa APA como de Interesse Especial e cria, em seu território, Reservas Ecológicas e Áreas de Relevante Interesse Ecológico. Há, além disso, Decreto Estadual oㅜ 750, de 1993, que proíbe a supressão de vegetação primária ou nos estágios avançado e médio de regeneração da Mata Atlântica. Esse último decreto gera controvérsias, pois não se poderia fazer quase nada ao que se refere à extração de plantas nativas, o que impediria a população local de obter renda por meio das samambaias silvestres. 
Samambaia Silvestre (Rumohra adiantiformis), ou seja, o que era uma atividade informal transformou-se numa atividade formalmente ilegal (SOARES, 2002).

O programa tinha como foco as famílias de baixa renda, que residiam longe do centro da Ilha, que tinham no comércio de samambaia sua principal fonte de sobrevivência. A pesca se constituía numa atividade secundária, assim como o trabalho informal no período de veraneio. Com as leis ambientais e a repressão policial, muitas pessoas migraram para os centros urbanos, causando uma pressão nos serviços de assistência social, além de levar à perda da identidade cultural da região e da dignidade desses moradores (SOARES, 2002).

A iniciativa começou a ser desenvolvida no ano de 1997, pela Prefeitura de Ilha Comprida, em parceria com a Universidade Federal de Santa Catarina, o Departamento Estadual de Proteção aos Recursos Naturais (DEPRN) - órgão da Secretaria de Estado do Meio Ambiente, o Instituto Brasileiro do Meio Ambiente e dos Recursos Naturais Renováveis (IBAMA) e organizações nãogovernamentais, impulsionada, sobretudo, pelos próprios extratores que se sentiam cada vez mais acuados e ameaçados em sua sobrevivência. A iniciativa fazia parte de um conjunto de ações municipais voltadas para o aproveitamento dos recursos naturais (vegetais e pesqueiros) da Ilha, de tal forma a constituir alternativas de trabalho e renda à população excluída do município (SOARES, 2002).

No ano de 1997, a Prefeitura fez um cadastro dos extratores de samambaia da Ilha, enfrentando muitas dificuldades, pois o individualismo e o medo dos órgãos de fiscalização, principalmente do IBAMA, fizeram com que os extratores relutassem em fornecer seus dados e informações necessárias para a devida compreensão das atividades que eram feitas por eles. Assim, foram necessárias diversas reuniões para ser conquistada a confiança dessas pessoas (SOARES, 2002).

Nesse mesmo ano, após tentar dialogar com algumas universidades paulistas, a Prefeitura fez uma parceria com a Universidade Federal de Santa Catarina, que enviou técnicos para a região, iniciando os estudos de campo. Os técnicos escolheram quatro áreas da Ilha, e em cada uma estabeleceram três parcelas de observação que seriam manuseadas, uma pelos técnicos, outra pelos extratores e uma terceira pelos dois grupos juntos. Após os primeiros resultados, constataram que a parcela explorada pelos extratores se recuperou rapidamente, e que as folhas renasceram mais fortes.

Este levantamento indicava que a maneira tradicional de exploração, além de não comprometer as samambaias silvestres, ainda propiciava a melhoria das folhas (SOARES, 2002). Devido à longa experiência nas matas, passada de geração para geração, os extratores não colhiam as folhas com esporos, por saberem que esse tipo de samambaia não tinha valor comercial e, além disso, que seria uma maneira de garantir a reprodução da espécie.

As folhas iniciam a produção de esporos na fase juvenil, quando ainda não apresentam aspecto ideal para comercialização; e o conhecimento científico ratificou a prática tradicional dos extratores de não colherem as samambaias em sua fase de reprodução. Tais estudos levaram à elaboração do Plano de Manejo da Espécie, com o intuito de legalizar e regularizar as atividades de extração. Assim, a elaboração do Plano de Manejo, dentro dos moldes legais, contou com os estudos científicos e com a experiência dos extratores (IIZUKA, 2008), (IIZUKA, 2010) e (SOARES, 2002). Conseguiram obter, assim, uma junção positiva entre conhecimento técnico, científico e prático para a obtenção de um modelo eficiente de exploração sustentada.

Além de legalizar a atividade dos extratores, reconheceram a importância de organizá-los. Assim, entre 1999 e 2000, formaram a Associação dos Manejadores das Plantas Nativas da Ilha Comprida (AMPIC). Essa Associação criou seu estatuto e estabeleceu regras, em comum acordo, para seus sócios. A partir disso, com o Plano de Manejo em mãos, a Associação conseguiu obter do DEPRN - Equipe Técnica de Iguape - a primeira licença do Brasil para exploração sustentada da samambaia silvestre no município de Ilha Comprida (IIZUKA, 2008) e (SOARES, 2002). E a legalização teve um efeito positivo na vida dos extratores de 
samambaia silvestre, tal como relata uma senhora que atua há mais de 10 anos com esta atividade: "melhorou para nós porque nós não temos mais medo de andar no mato, né, antes a gente tinha medo".

Com a criação da Associação, constataram que os extratores não faziam parte de uma categoria (não pertencem nem à categoria dos pescadores e nem à dos trabalhadores rurais) e por isso não poderiam contribuir para o Instituto Nacional de Seguridade Social (INSS) e usufruir de direitos como a aposentadoria, licença-maternidade etc. Nesse sentido, um dos objetivos do programa, que ainda está em andamento, é a organização da categoria e a legalização da profissão perante o (INSS) o que resultou numa nova profissão. Além disso, apesar de a prefeitura apoiar os extratores, o sentimento de medo entre eles ainda se faz presente, conforme palavras de um deles: "mesmo com a carteirinha pra gente dá um pouco de medo".

A Prefeitura de Ilha Comprida estima que, nos dois primeiros anos, investiu cerca de $\mathrm{R} \$ 50.000,00 \mathrm{em}$ estudos técnicos e em pesquisa. Além disso, a Prefeitura cedeu ao Programa três funcionários, sendo um motorista de caminhão e os outros dois gerentes comerciais responsáveis pelo transporte e venda do produto em Campinas e em São Paulo. Em média, desde o primeiro semestre de 2000, a AMPIC tem obtido um saldo positivo em suas atividades, apontando para a viabilidade econômico-financeira dessa iniciativa (SOARES, 2002) e (IIZUKA, 2008).

\section{O Contexto em que foi Desenvolvido o Programa de Extrativismo da Samambaia}

A atividade de extração da samambaia silvestre sempre foi uma alternativa de renda, principalmente para a população analfabeta ou semianalfabeta. Entretanto, com a adoção gradual de uma legislação ambiental, essa atividade foi colocada na clandestinidade. Nesse contexto, alguns dos extratores apresentaram uma preocupação com a sua sobrevivência. Em meio à fiscalização ambiental, os extratores foram obrigados a trabalhar durante as madrugadas e escondidos dos policiais e fiscais, o que foi reforçado pela lembrança de um dos extratores ao falar sobre a Zefinha que, além de extrair as samambaias silvestres, ensinou esta atividade a outras pessoas: "ela já cortava há muito tempo, fazia o que a gente fazia antes de ser associado, cortava meio escondido então ensinou a gente".

Segundo o funcionário do DEPRN, havia a compreensão de que a atividade dos extratores de samambaia deveria ser legalizada, mas o processo administrativo do DEPRN exigia uma série de procedimentos, conforme sua argumentação "[...] queríamos estar autorizados para fazer isso antes. [...] Quer dizer, não foi assim uma coisa vamos fazer. Eles mandaram para o botânico. Teve registro para prosseguimento [...] A mesma coordenadora do IBAMA sendo cutucada por nosso ex-chefe, aqui, para fazer o esquema pedagógico, pesquisa de campo".

Esse mesmo entrevistado reconheceu a relevância social e econômica da legalização e organização da atividade produtiva dos extratores, pois, conforme suas palavras: "[...] são cerca de 250 pessoas trabalhando com as samambaias e o principal empregador do município é a prefeitura que dá 700 empregos, então é muito significativo." E essa visão sobre a importância de um projeto de manejo da samambaia silvestre foi compartilhada por outros entrevistados, tais como o vice-prefeito, o ex-prefeito de Ilha Comprida e também pelos próprios extratores, tal como segue: "na época (início) era pouquinho, mas hoje nós somos em cento e poucas famílias".

\section{O Fluxo de Ações na Construção do Projeto de Manejo da Samambaia Silvestre em Ilha Comprida}

Para que se efetivasse o projeto, diversos profissionais foram mobilizados, cada qual com um saber específico, tal como descreveu o então prefeito de Ilha Comprida: “[...] então teve esse profissional do 
IBAMA, teve a Atlântica Assessoria Agroambiental e a Universidade Federal de Santa Catarina." Além desses profissionais, a comunidade local foi crucial para o projeto, conforme argumentou o então representante do IBAMA para o estado de São Paulo:

[...] pela minha experiência também aqui, os planos de manejo na prática, na prática, quase sempre vêm para confirmar o que já é o senso comum [...]. Os estudos feitos posteriormente só vieram confirmar que a portaria realmente é correta e precisa o que mostra a ética na conservação. Ou seja, você fazer as coisas ouvindo a população [...] você pega uma informação lá do mateiro, pega a informação do caiçara, você pega informação dos índios [...] tirando a média das opiniões.

A argumentação do ex-prefeito de Ilha Comprida reforça a importância de um saber que dificilmente é adquirido nos bancos escolares, ele destaca a relevância do saber popular ou cotidiano de quem convive a população das florestas, e isso contribuiu para o seu posicionamento em relação aos extratores de samambaia: "[...] a gente se apropria indevidamente desse patrimônio sem aguardar que ele cumpra o ciclo dele na natureza. Então, sem dúvida nenhuma, o projeto da samambaia ele utiliza o aprendizado obtido na minha adolescência (com os moradores da floresta)".

Entretanto, a sociedade nem sempre reconhece esse tipo de saber, muitas vezes o nega, ou o negligencia. Os extratores tinham um conhecimento tácito da extração da samambaia silvestre constituído ao longo de anos de trabalho na floresta, conforme descreve um deles:

[...] você chega num lugar aqui que está cheio de samambaia, mas está tudo seco, aí você pega e corta tudo aquilo ali e joga fora. Daqui trinta, trinta e cinco dias você volta e está tudo bonito [...] se cortar todos os talinhos ruins que têm na ilha, daqui a trinta, quarenta dias aquilo vai estar tudo bonito, então tem que cortar é a natureza da planta [...] porque ela tem o ponto certo. Coisa de uma semaninha a mais ou uma semaninha a menos, dá uma diferença $[\ldots]$.

Contudo, para que houvesse a possibilidade de um diálogo "legítimo", foi necessário buscar um respaldo em organizações científicas, assim como em organizações que são reconhecidas, tradicionalmente, como portavozes de um saber válido, conforme disse o ex-prefeito:

[...] mas isso não estava colocado cientificamente. Então, a partir daí nós conseguimos convencer o IBAMA, que tinha um escritório local em Iguape. E o IBAMA foi um dos parceiros junto à Universidade Federal de Santa Catarina, para estabelecer parcelas junto com a população local para determinar parâmetros de poda e disseminação da espécie. Qual não foi a nossa surpresa, quando terminou os trabalhos: o plano de manejo que queria se determinar para a espécie era exatamente aquilo que a comunidade fazia.

Por outro lado, havia a necessidade de ser constituído um plano com uma fundamentação técnica, conforme relembrou o ex-prefeito: "nós tínhamos essa necessidade de conhecimento, por conta da área de proteção ambiental, era uma condição específica [...] fomos buscar a universidade para escrever cientificamente aquele saber."

O programa dos Extratores de Samambaia, além da própria prefeitura, contou com o apoio dos governos Estadual e Federal, uma articulação que nem sempre é simples de ocorrer. A agenda de políticas públicas entre os diferentes níveis governamentais dificilmente encontra-se em sintonia mediante as diversas demandas a que buscam atender. Nesse contexto, a configuração de uma determinada política pública 
depende de uma complexa combinação de fatores e interesses. Nesse sentido, o representante do IBAMA para o estado de São Paulo argumentou o seguinte:

[...] há sempre um descompasso entre a pré-consciência, o recurso e o técnico, o técnico e o momento político de tal maneira que eles não acontecem conforme o modelo. Eles acontecem conforme a possibilidade. E aqui, por exemplo, casou essa oportunidade, um raro momento em que o Governo do estado, o Governo Federal, o DEPRN e o IBAMA trabalharam de uma maneira afinada. Um prefeito interessado, um projeto viável e não muito difícil de resolução, então as coisas foram acontecendo.

O representante do IBAMA argumentou acerca da importância do protagonismo dos governos locais nesse processo de interlocução com os demais órgãos governamentais, nas suas diferentes instâncias: "[...] tem muita coisa a ser feita. Tem outras coisas acontecendo, tem outros projetos, tem outras necessidades. Então, se os prefeitos, se os agentes locais não fizerem, eles nesse papel de garantidor de que as coisas aconteçam, não acontece nada."

Ademais, a partir das falas dos entrevistados, foi possível perceber que o estilo de gestão adotado na prefeitura de Ilha Comprida foi marcado pela flexibilidade, fluidez e descentralização. A respeito disso, um dos funcionários da prefeitura relembrou o seguinte:

[...] ele [prefeito] sempre batia na mesma tecla. Eu quero que vocês arrumem coisas para o povo ganhar dinheiro [...] Ele pedia para bolar alguma coisa, pensa, entra na internet, pega livro para dar emprego para esse pessoal (...) Fora as ideias dele, ele forçava a gente a usar a cabeça também [...] Ele falava estuda, fuça [...] tinha autonomia para bolar o que quisesse, [o prefeito dizia] Faz o que você quiser.

E essa forma simples, flexível e fluida de gestão esteve presente nos outros órgãos, conforme declarou o então representante do IBAMA no estado de São Paulo: "IBAMA e DEPRN foi o único lugar no Brasil que Estado (SP) e Governo Federal trabalhavam harmonicamente, a gente tocava de ouvido porque com muita confiança mútua, muito respeito mútuo."

Questionados sobre se as decisões eram baseadas em modelos e teorias e se o projeto fosse planejado detalhadamente, e rigidamente conduzido, o profissional do IBAMA argumentou o seguinte: "não aconteceria, eu tenho absoluta certeza as pessoas vivem com cartilha na cabeça, as pessoas vivem com receitas de bolo na cabeça, e não é assim, a vida da gente não é assim." Numa linha semelhante, o então prefeito falou: "eu estava ali livre de amarras porque se estivesse preso, talvez eu não tivesse conseguido. Eu estava solto [...] o que nós fizemos? [...] Potencializamos uma ação [...]. Isso já era uma vocação."

A postura do ex-prefeito de respeito aos diferentes saberes, durante a construção e a implantação do programa de manejo da samambaia silvestre, contou com sua experiência quando era adolescente, conforme seu relato. Esse é apenas um exemplo de que a análise do fluxo de ações e o processo decisório dificilmente se resumem ao período de construção dos projetos e programas.

Sobre as práticas e as ações ao longo do processo de formulação e implantação do Projeto, o vice-prefeito relembrou que, muitas vezes, ao invés de aguardar os extratores na sede da prefeitura, os gestores foram ao encontro deles, tal como segue:

[...] o prefeito vestiu a camisa muito, muito. Ele estava junto em todos os movimentos que a gente procurava sentar para conversar. Eu convidava, e ele é um grande articulador. Ele me ajudou muito. Não é assim, é assim. Se fizer desse jeito não fica melhor. Vestiu a camisa 
mesmo para que a coisa andasse [...] Era muito difícil chegar até lá. Então vamos ao encontro deles. É melhor sair em dois ou três da prefeitura do que levar dez, quinze para lá.

E esse estilo de trabalho, ou seja, de andar e conversar com as pessoas, buscando um contato direto com elas, parece fazer parte do histórico do então prefeito, pois, segundo suas palavras: “[...] trabalhei num depósito de material de construção e lá eu conversava com o ajudante, com o pedreiro, com o dono da obra, o arquiteto, o engenheiro, então eu tinha um gradiente de comunicação social. Eu conseguia me comunicar com diferentes públicos."

Por outro lado, de acordo com o representante do IBAMA, há diversas amarras institucionais, baseadas em normas e regras, e em que se deixa pouco espaço para o diálogo e a construção de novas práticas, conforme as suas palavras:

[...] que mundo é esse? Um mundo todo normatizado, o positivismo venceu, não tem mais a incerteza. Não tem mais a imprevidência. Não tem mais diálogo. A possibilidade de iniciativa, de construir alguma coisa, o lampejo das pessoas gerarem inovações. É um mundo todo regulamentado, não tem cabimento [...] O mundo foi construído com o princípio da incerteza, o que nos move é a incerteza.

De forma indireta, o entrevistado defendeu a prática de tatear possibilidades, de criar novas alternativas e de reconhecer que a realidade não pode ser confinada a um conjunto de regras e normas. Nesse sentido, conforme a linha de raciocínio do representante do IBAMA, as pessoas teriam poucas possibilidades de controle antecipado, mas, em vez disso, poderiam interagir e agir sobre a realidade: "[...] a consciência quando você está mergulhado no problema não é assim tão acentuada. Você vai interagindo com a coisa conforme a música, não dá para dizer que você está com o tempo inteiro com essa consciência de que estão fazendo história. Isso aí é uma história para boi dormir. Você vai fazendo as coisas".

Nesse mesmo sentido, o então prefeito comentou sobre dinâmica de tentativas e experimentos que foram feitos, revelando um processo não linear, em que os resultados vão ajudando a guiar os passos seguintes, tal como segue: "[...] não é tão linear, porque você planeja, executa, não dá o resultado, aí tem que voltar, vai abrindo possibilidades." E esse fluxo de ações não linear foi percebido por um dos funcionários da prefeitura de Ilha Comprida sobre o início da implantação do Programa:

[...] foi uma loucura porque ninguém sabia nem como começar. Então demorou e tudo. Agora você chega e pega o negócio com nota fiscal, licença e tudo [...] Era tocar uma firma. A gente tinha que pegar do pessoal do mato, armazenar ela. Combinar com o comprador que vinha comprar. Depois o comprador não levava tudo porque todo mundo começou a colher. Ele começou a ter uma quantidade meio grande e teve que levar para o mercado.

Dessa forma, o período de implantação foi de aprendizados contínuos, tal como argumentou o ex-prefeito: "nós fomos para outro processo que era viabilizar a organização dessa extração e da comercialização porque todo mundo imaginava a questão de tirar o atravessador, e aí começamos um processo de aprendizagem." Pelo que se pode perceber, possibilidades foram testadas, na prática, e os resultados influenciaram os passos seguintes. Por outro lado, alguns fatos e ações que ocorreram antes do lançamento do Projeto contribuíram na construção de sentidos. Um exemplo disso foi o relato do então representante do IBAMA:

[...] me ligaram da delegacia de polícia que haviam apreendido uma Kombi cheia de samambaia e uma família de extratores [...] Cheguei lá e para a minha surpresa tinha menores, crianças, eles estavam sentados no banco. Eu passei por eles e disse: não acredito vocês de novo! [...] Eu já os conhecia de outros carnavais. Mas vocês não aprendem nunca. 
A senhora levantou e disse: o senhor quer que a gente viva do quê? Aquele negócio me calou fundo porque eu não tive resposta na hora. A resposta, na verdade, foi o projeto.

A partir disso, o representante do IBAMA na época procurou o prefeito e fez a seguinte indagação: "e se nós buscássemos legalizar essa atividade. E aí o prefeito disse: mas isso é possível? Você acha que tem jeito? Aí eu falei: sei lá, só saberemos disso tentando". Por meio desse relato, percebe-se a importância de dois aspectos: o episódio com a moradora que fora presa por extrair samambaia foi o ponto de partida que fez sentido para o representante do IBAMA buscar uma solução para os extratores, sem que houvesse um relatório técnico ou uma informação sistematizada das reais condições de vida dessa parcela da população. Também foi dada a ênfase na ação, mais do que em planejamentos detalhados.

E a maneira pela qual isso foi sendo construído, paulatinamente, foi relatada pelo vice-prefeito: “[...] trabalho idôneo, honesto. Eles traziam a nota lá do CEASA para mostrar para eles como era vendida e dentre esse custeio de tirar esse 5\%. Tirava-se simplesmente a despesa de óleo, aí descontava e abatia no custo de retorno para eles".

Por outro lado, houve momentos em que a improvisação foi necessária. A utilização de determinados recursos de uma forma flexível e que fizesse sentido foi relembrada pelo profissional do IBAMA, e tal prática apresentou-se como relevante ao andamento do programa:

[...] era assim: ora o técnico para ir a campo usava o veículo do DEPRN e o combustível do IBAMA. Ora usava o veículo do IBAMA, o combustível do DEPRN. E a prefeitura pagava a alimentação dele. Nós tínhamos que fazer das tripas coração para ir superando as dificuldades porque não havia recursos [...] $\mathrm{O}$ resto era improvisação, um pagava o hotel, o outro arranjava combustível, o outro pagava a alimentação, quem tinha um recurso ajudava ali. Era uma coisa improvisada, mas era o que tinha, a gente não tinha no momento nem recursos e nem outros meios de gente outra que pudesse fazer.

Ou seja, se houvesse uma ênfase demasiada nas regras e "amarras" institucionais, é pouco provável que o programa da samambaia silvestre tivesse saído do papel. Outros sentidos foram sendo construídos, mesmo após a implantação do Programa. Relembrando o momento da premiação recebida pelo Programa Gestão Pública e Cidadania (PGPC), em 2001, o ex-prefeito de Ilha Comprida havia questionado o Coordenador do PGPC: "afinal, o que estou fazendo aqui? Sou de uma pequena prefeitura e fizemos algo extremamente simples!" E ele relembrou a resposta recebida: "[...] no momento do processo de desenvolvimento econômico todo dia está (se) destruindo produções, e você cria uma nova profissão." A sua visão inicial, porém, era a de tentar "resolver um problema de boca e do bolso daquela comunidade."

A percepção de um dos funcionários da prefeitura sobre a importância do programa com os extratores de samambaia foi a seguinte: "uma das coisas gratificantes nessa época aí, você conseguir fazer a pessoa ter alguma coisa, a gente que tem essas coisas a gente não dá valor [...] o cara hoje pode fazer um churrasco com carne do açougue, antigamente era carne de tatu, capivara que também é ilegal." Dito de outra forma, para essa pessoa foram fundamentais as experiências construídas com os extratores, pois viu que eles melhoraram sua qualidade de vida. Isso que fez mais sentido para ele, não foi a premiação, nem tampouco a criação de uma nova categoria profissional.

\section{Gestão do Território do Vale do Ribeira e Relações com a Cidadania Deliberativa}

A participação de diferentes atores locais vistos sob o prisma do fluxo de ações e do processo decisório permite reflexões complementares para o campo da gestão social do território e, neste contexto, da cidadania 
deliberativa. De início, parece ser necessário apresentar, a questão do desenvolvimento local, pois conforme argumentou Tenório (2004, p. 2), "a lógica do desenvolvimento local necessita do surgimento e fortalecimento de atores inscritos em seus territórios e com capacidade de iniciativa e propostas socioeconômicas que capitalizem as potencialidades locais, apostando em uma melhora integral da qualidade de vida da população". A experiência em Ilha Comprida, de acordo com entrevistas e informações coletadas, parece apontar para esta perspectiva de desenvolvimento.

A favor de uma ênfase no desenvolvimento territorial tem-se o fato de que os desafios e características locais impulsionam ou restringem a comunidade local para, em conjunto com a diversidade de atores institucionais, possam traçar estratégias que fortaleça suas capacidades na solução dos problemas. No caso da extração de samambaias em Ilha Comprida consideraram-se as cinco dimensões de gestão do território sugeridas por Tenório (2004) para analisar o processo decisório e da cidadania deliberativa. O Quadro 2 mostra os fatores impulsionadores e restritivos à cidadania na Ilha Comprida.

\section{Quadro 2}

Fatores impulsionadores e restritivos à Cidadania na Ilha Comprida

\begin{tabular}{|l|l|}
\hline \multicolumn{1}{|l|}{ Fatores impulsionadores } & \multicolumn{1}{c|}{ Fatores restritivos } \\
\hline - $\begin{array}{l}\text { Controle social das políticas } \\
\text { públicas }\end{array}$ & $-\quad$ Alienação social \\
- Interesse pelo desenvolvimento & $-\quad$ Exclusão econômica, social, cultural e política \\
sustentável & $-\quad$ Individualismo \\
- Participação popular & $-\quad \begin{array}{l}\text { Valores tradicionais (assistencialismo, } \\
\text { clientelismo, paternalismo, coronelismo, } \\
\text { machismo, entre outros) }\end{array}$ \\
- Valoriza os interesses coletivos & \\
\hline
\end{tabular}

Fonte: dados da pesquisa.

Os extratores de samambaia silvestre encontravam-se isolados e pouco informados sobre a legislação ambiental e por essa razão foram surpreendidos pela ação da polícia ambiental. De fato, a situação vivida pelos extratores era de exclusão social, cultural e política. A prefeitura e os demais órgãos governamentais tendiam a ignorar a relevância da atividade do extrativismo para os moradores, assumindo, muitas vezes, uma posição unilateral, revelando uma perspectiva individualista e legalista. Com o início do programa da samambaia silvestre, avançou-se no sentido de valorização dos interesses coletivos, bem como das questões sociais. Esse processo de participação popular propiciou um aumento no controle das políticas públicas em Ilha Comprida, despertando no âmbito local o interesse pelo desenvolvimento sustentável (conciliação entre o econômico, o social e o ambiental). O Quadro 3 mostra os fatores impulsionadores e restritivos à participação da sociedade civil na Ilha Comprida. 
Quadro 3

Fatores impulsionadores e restritivos à participação da Sociedade Civil em Ilha Comprida

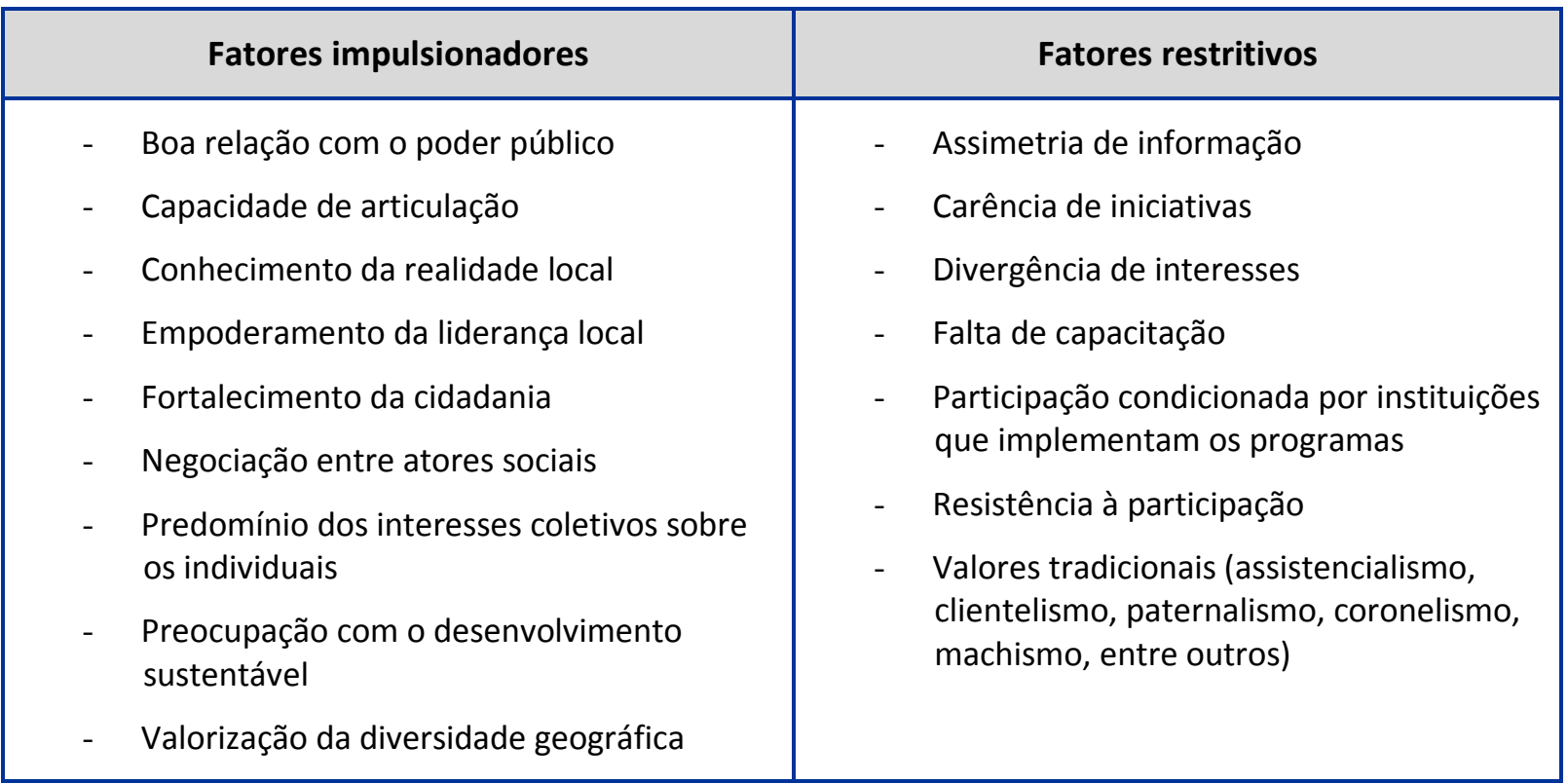

Fonte: dados da pesquisa.

Assim como em outros municípios, em Ilha Comprida os gestores públicos não tinham capacitação técnica prévia para conduzir o programa da samambaia silvestre. Por essa razão, talvez, havia falta de iniciativas e a participação desses gestores se restringia ao que as demais esferas governamentais promoviam em seus programas e projetos. A situação nesse município não difere do que se encontra nos pequenos municípios brasileiros, ou seja, assimetria de informações, valores tradicionais e a resistência à participação. O Quadro 4 mostra os fatores impulsionadores e restritivos à articulação do capital social na Ilha Comprida.

\section{Quadro 4}

Fatores impulsionadores e restritivos à articulação do capital social em Ilha Comprida

\begin{tabular}{|c|c|}
\hline Fatores impulsionadores & Fatores restritivos \\
\hline $\begin{array}{ll}\text { - } & \text { Boa relação com o poder público } \\
\text { - } & \text { Construção de redes } \\
\text { - } & \text { Capacidade de articulação } \\
\text { - } & \text { Diálogo com poder público e a sociedade } \\
\text { civil } \\
\text { - } \quad \text { Flexibilização } \\
\text { - } \quad \text { Interesse pelo desenvolvimento sustentável } \\
\text { - } \quad \text { Valoriza a criação de redes no município }\end{array}$ & 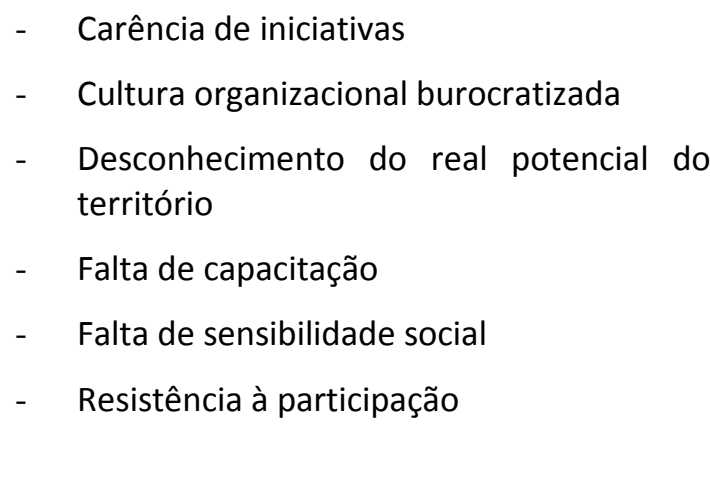 \\
\hline
\end{tabular}

Fonte: dados da pesquisa. 
A partir de 1993, por meio do Decreto Estadual no 750, o município de Ilha Comprida deparou-se com a ilegalidade na atividade extrativa da samambaia silvestre. A partir daquele momento, os extratores, que tradicionalmente sobreviviam dessa atividade, passaram a enfrentar mais uma dificuldade, além da pobreza, falta de infraestrutura, educação precária entre outros, a de ser considerados infratores. Sem muitas alternativas de trabalho e renda na região, muitos viviam na clandestinidade e sujeitos a serem presos a qualquer momento. Ainda que a maioria não tivesse estudos formais, os extratores sabiam que a sua atividade não era prejudicial à natureza, ao contrário disso, pois quanto mais colhiam as folhas da samambaia em idade adulta, mais elas renasciam fortes e saudáveis.

Contudo, não era possível continuar a fugir da polícia e viver escondido no meio do mato. Indignados com essa situação, buscaram dialogar com o poder público local, para que pudessem trabalhar mais tranquilos. Nesse contexto, alguns vereadores se mobilizaram e encaminharam aos órgãos competentes a solicitação para que os extratores pudessem se legalizar. Essa primeira tentativa, porém, não surtiu resultado, e o problema continuou. Foi assim que os extratores buscaram apoio junto da prefeitura que, sensibilizada pela situação, passou a apoiá-los.

Por outro lado, o medo e a desconfiança dos extratores eram muito grandes, o que fazia sentido, na medida em que foram colocados frente a frente com representantes dos órgãos que os perseguiam. A prefeitura, neste contexto, serviu como uma espécie de "ponte", interligando diferentes saberes. Isto nos remete ao pensamento de Abramovay (2001) de que a vitória sobre a pobreza não poderá vir apenas da mobilização das forças do município, mas, sobretudo, em sua capacidade de ligar-se a atores sociais entre indivíduos que não pertencem à vida cotidiana local. Além disso, Abramovay (2001) descreveu o vínculo entre os indivíduos que têm um "formato de ponte", ou seja, a capacidade de um determinado grupo de ampliar o círculo de relações em que se movem os indivíduos, além daqueles que participam imediatamente de sua vida social.

Assim, foram convidados a participar diversos órgãos, tais como o IBAMA, o DEPRN, a Universidade Federal de Santa Catarina e uma empresa de consultoria ambiental. A articulação entre os diferentes órgãos, em âmbito estadual e federal, assim como com organizações locais, foi permeada de negociações e, passo a passo, os obstáculos foram sendo superados, não de forma totalmente planejada, mas com liberdade para a ação, tanto no âmbito da prefeitura, como também nos órgãos envolvidos, principalmente no IBAMA e DEPRN. Nesse sentido, os gestores públicos de Ilha Comprida tinham clareza sobre os objetivos, mas não o caminho exato a ser percorrido. A prática dos gestores de estarem próximo às pessoas, em suas comunidades, contribuiu, em alguma medida, na compreensão das demandas da população. Assim, os resultados obtidos ao longo do processo de formulação e implantação da proposta foram guiando os gestores rumo à legalização da atividade extrativa. Nesse contexto, os sentidos do que estava sendo feito foram emergindo de forma contínua, não de forma homogênea, pois cada um dos atores percebeu os resultados e o processo, em geral, de forma distinta.

Além disso, as experiências passadas durante a juventude do ex-prefeito, a vinculação do vice-prefeito com as atividades de extração da samambaia há mais de 50 anos, assim como a atividade de conclusão de curso do profissional do DEPRN, emergiram ao longo da formulação e implantação da proposta de manejo da samambaia silvestre em Ilha Comprida. Esses repertórios parecem ter contribuído para o êxito da proposta e podem indicar um processo não linear de tomada de decisão, em que "soluções buscam problemas".

Em suma, com o programa da samambaia silvestre houve a possibilidade de se conhecer com mais nitidez a realidade local e isso ocorreu por meio de negociações entre os diferentes atores. E essa aproximação com o poder público em suas diferentes instâncias e esferas propiciou um ambiente favorável à articulação e em que os interesses coletivos prevaleceram aos individuais. Com isso, reconheceram-se e valorizaram-se as características locais, assim como os papéis das diferentes lideranças (especialmente no "empoderamento" dos líderes extrativistas), o que foi ressaltado por um dos extratores: "[...] quem mexe com tudo isso aí somos nóis (sic), esse negócio de reunião sou eu, a minha esposa, o seu Romeu, o pessoal que trabalha na 
floresta”. O Quadro 5 mostra os fatores impulsionadores e restritivos à articulação do poder público na Ilha Comprida.

\section{Quadro 5}

Fatores impulsionadores e restritivo à articulação do poder público em Ilha Comprida

\begin{tabular}{|c|c|}
\hline Fatores impulsionadores & Fatores restritivos \\
\hline $\begin{array}{l}\text { - } \quad \text { Atendimento das necessidades segundo o } \\
\text { - } \quad \text { Compritório } \\
\text { com a coisa pública } \\
\text { - } \quad \text { Diálogo com mercado e a sociedade civil } \\
\text { - } \quad \text { Diálogo com outros poderes públicos } \\
\text { - } \quad \text { Democratização do poder público } \\
\text { - } \quad \text { Descentralização } \\
\text { - } \quad \text { Estimula a criação de redes } \\
\text { - } \quad \text { Flexibilização } \\
\text { - } \quad \text { Prática dos direitos civil, social e civil } \\
\text { - } \quad \text { Projetos de inclusão social } \\
\text { - } \quad \text { Promoção da identidade local } \\
\text { - } \quad \text { Promoção da vocação econômica } \\
\text { - } \quad \text { Reconhecimento das organizações da } \\
\text { sociedade civil } \\
\text { - } \quad \text { Trabalhar com instrumentos de } \\
\text { planejamento } \\
\text { - Trabalhar com métodos participativos } \\
\text { (orçamento participativo, planejamento } \\
\text { participativo, entre outros) }\end{array}$ & $\begin{array}{l}\text { - } \quad \text { Assimetria de informação interna } \\
\text { - } \quad \text { Conflito de competências entre os poderes } \\
\text { - } \quad \text { Crise de representatividade dos poderes } \\
\text { públicos } \\
\text { - } \quad \text { Dependência do poder público estadual } \\
\text { - } \quad \text { Dependência do poder público federal } \\
\text { - } \quad \text { Falta de capacitação do quadro funcional }\end{array}$ \\
\hline
\end{tabular}

Fonte: dados da pesquisa.

Os pequenos municípios brasileiros, em geral, têm um alto grau de dependência dos poderes estadual e federal e em Ilha Comprida isso não era diferente. Além disso, em função da mudança da legislação ambiental, foi possível perceber conflitos entre as diferentes instâncias e órgãos governamentais - IBAMA, DEPRN e Prefeitura - sobre a legalização ou não da atividade extrativista. Os extratores, por sua vez, não confiavam nos poderes públicos, pois eram constantemente perseguidos e punidos por extraírem das florestas a sua sobrevivência. Por trabalharem uma vocação econômica do território e em especial desse município, fortaleceu-se a identidade local a partir de constantes diálogos entre os poderes públicos, sociedade civil e mercado. Com o uso de instrumentos de planejamento, os funcionários públicos, bem como da sociedade civil, puderam estimular a formação de redes entre os extratores e isso atendeu a contento à demanda local. 
A atividade extrativista ocorria há muitos anos em Ilha Comprida. Contudo, foi a partir do programa da samambaia silvestre que o potencial da extração da samambaia silvestre se revelou de maneira cristalina. Por outro lado, a experiência nesse município demonstrou o alto grau de dependência do setor público em encontrar alternativas para a geração de emprego e renda para a população local. Conforme descrito anteriormente, o respeito à vocação econômica, bem como o envolvimento dos diferentes atores nessa iniciativa, possibilitou novas parcerias e a criação e fortalecimento de redes. O Quadro 6 mostra os fatores impulsionadores e restritivos à alavancagem do potencial do território de Ilha Comprida.

\section{Quadro 6}

Fatores impulsionadores e restritivos à alavancagem do potencial do território de llha Comprida

\begin{tabular}{|c|c|}
\hline Fatores impulsionadores & Fatores restritivos \\
\hline $\begin{array}{ll}\text { - } & \text { Existência de parcerias } \\
\text { - } & \text { Existência de redes } \\
\text { - } & \text { Extensão rural } \\
\text { - } & \begin{array}{l}\text { Infraestrutura social (saúde, educação, } \\
\text { cultural e assistencial) }\end{array} \\
\text { - } & \text { Legislação } \\
\text { - } & \text { Potencial turístico } \\
\text { - } & \text { Recursos humanos } \\
\text { - } & \text { Recursos naturais } \\
\text { - } & \text { Vocação econômica }\end{array}$ & $\begin{array}{l}\text { - Dependência do poder público na geração } \\
\text { de empregos } \\
\text { - } \quad \text { Desconhecimento do potencial do território }\end{array}$ \\
\hline
\end{tabular}

Fonte: dados da pesquisa.

A perspectiva apresentada por Tenório (2004) contribuiu para analisar a iniciativa ocorrida em Ilha Comprida no que refere ao desenvolvimento local e cidadania. Esta análise, por sua vez, abre um espaço para a reflexão sobre a gestão social, assim como sobre a prática de cidadania deliberativa ocorrida neste território, na medida em que foi analisada a relação entre as diferentes esferas e atores.

\section{Considerações Finais}

O objetivo deste artigo foi analisar, sob a ótica do processo decisório e da cidadania deliberativa, a participação de diferentes atores na construção do Programa de extração de samambaia silvestre que ocorreu no município de Ilha Comprida. Nesse sentido, o caso dos extratores da samambaia silvestre reforça a argumentação sobre os desafios em se estabelecer os contornos do processo decisório, na medida em que fatores pouco evidentes e difíceis de serem capturados, como a história de vida dos atores, a influência das emoções e intuição humana, as complexas relações entre os diferentes níveis governamentais, a dinâmica social do local, entre outros; além disso, a combinação de diferentes saberes, lógicas e repertórios, parecem ser dignos de menção.

Por outro lado, deve-se reconhecer que este caso foi relevante no sentido de acrescentar novos elementos nos debates sobre a cidadania deliberativa. Foi possível perceber uma aproximação teórica de parte da literatura 
administrativa com a abordagem da cidadania deliberativa. Além disso, as falas e descrições dos diferentes atores foram relevantes no sentido de agregar mais elementos na compreensão do processo de participação as dificuldades, os dilemas, as angústias, as expectativas, entre outras situações vividas pelos atores.

O êxito desta experiência local ocorrida no Território da Cidadania do Vale do Ribeira em São Paulo explica-se não só pela intenção explícita do corpo técnico e da prefeitura em estimular a mais ampla participação dos extratores de samambaia silvestre nas decisões e em buscar formas não convencionais de geração de renda, mas também pela própria história, potenciais e limitações do território em que se insere.

Sendo assim, a pesquisa buscou entender a articulação dos diferentes atores, políticas públicas e práticas na busca de soluções integradas para a gestão social num território. Neste contexto, pode-se descrever o fluxo de ações e o processo decisório, ocorrido no projeto de extração da samambaia silvestre em Ilha Comprida, da maneira a seguir indicada.

Houve a conjugação de diferentes saberes, desde o tácito até o acadêmico, passando pelo político, construídos a partir de um processo contínuo de negociações e construção de sentidos, em distintos âmbitos governamentais e da sociedade civil. Essa dinâmica fazia parte de uma gestão fluida e flexível, e em que se pode utilizar, livremente, a intuição, os erros, os acertos e também os resultados. Os gestores ficaram próximos às pessoas e foram tateando as possibilidades que emergiam ao longo do tempo, e os obstáculos foram superados paulatinamente, de forma não linear. Ou seja, tanto um determinado problema abriu outras possibilidades de ação como determinadas soluções também geravam novos problemas. Em função da história de vida de determinados atores, restou a percepção de que determinadas soluções existiam antes do projeto e foram utilizadas de modo não linear, ou seja, de um modo em que "soluções buscam um problema", configurando, provavelmente, um processo de "caos organizado".

Sob o aspecto da cidadania deliberativa, o caso de Ilha Comprida permitiu evidenciar diversos fatores restritivos e impulsionadores nas dimensões de cidadania, sociedade civil, capital social, poder público e potencial do território. A necessidade de sobrevivência dos extratores da samambaia silvestre mediante a mudança da legislação ambiental estadual funcionou como uma espécie de catalisador das mudanças locais. Foi um sentimento coletivo de solidariedade que permeou a participação dos distintos atores e a comunicação ocorreu de maneira fluida e participativa. Os atores, assim, dialogaram de maneira intersubjetiva e buscaram avançar em torno de questões coletivas.

Retomando-se as questões que nortearam o estudo, a primeira refere-se à relevância dos processos decisórios na gestão social em um determinado território. De acordo com as percepções dos atores, a lógica racional, baseada na maximização da utilidade econômica e focada num processo decisório individual, não parece ser adequada para explicar as decisões e o processo decisório em Ilha Comprida. Dito em outras palavras, a experiência dos extratores de samambaia silvestre contraria a lógica de gestão estratégica, como disse Tenório (2009), abordagem predominante na Administração. De fato, a participação de diferentes atores, tendo como base o diálogo constante e livre de coerções, evidenciou uma gestão social, a qual se distancia de uma forma de gestão individualista e utilitarista, posto que foi baseada, ao longo do processo, sobretudo, por uma lógica humana e solidária (TENÓRIO, 2005).

A pesquisa sugere, assim, que são as proposições dos processos decisórios menos lineares e as abordagens de formulação de políticas públicas que enfocam as práticas cotidianas dos gestores - permeadas pelas imperfeições e deselegâncias do dia a dia - que melhor contribuem para sua compreensão. Ademais, deve-se observar que a valorização da vocação local, historicamente construída neste território, de atividades de extrativismo da samambaia silvestre, constituiu-se como um mote para que os atores locais de Ilha Comprida pudessem exercitar a cidadania deliberativa.

Enfim, se é verdade que territórios podem ser estudados a partir dos laços sociais entre seus atores, então é fundamental que em estudos futuros, conforme convida Abramovay (2006) se "compreenda teoricamente a 
natureza destes laços, ou seja, a natureza do processo de cooperação em torno do qual se constroem os territórios. Este processo será importante na compreensão das instituições públicas e dos próprios mercados que marcam a vida de uma região".

No que se refere à segunda questão de pesquisa, "como relacionar a participação dos diferentes atores locais sob a perspectiva da gestão social e da cidadania deliberativa?" Pode-se argumentar que a experiência em Ilha Comprida é um caso empírico do que seja uma gestão social, pois, conforme argumentou Tenório (2005), ela se caracteriza pela participação, dialogismo e em que o processo decisório é compartilhado por diferentes sujeitos. De fato, houve a participação de diferentes atores em distintas etapas no processo de construção da experiência, o qual foi permeado pelo diálogo entre os sujeitos e, finalmente, o processo decisório foi construído pelos diferentes atores locais. Ademais, deve-se observar que ao longo do processo houve a busca pela concordância, em que o outro (extrator de samambaia silvestre) deveria ser incluído e boa parte das perspectivas de ação das pessoas envolvidas foi motivada pela solidariedade (TENÓRIO, 2005).

Diante da situação vivida pelos extratores de samambaia silvestre, houve uma união entre os atores locais por compreenderem que a situação de ilegalidade enfrentada pelos trabalhadores era injusta e incorreta. Nesse sentido, ocorreu um autoentendimento ético (Tenório, 2005), a partir do qual ocorreram debates e negociações na busca por uma solução pragmática diante das demandas ocorridas a partir da nova legislação ambiental no estado de São Paulo. Neste contexto de participação, os gestores públicos de Ilha Comprida, assim como atores da área privada local, não se apresentaram com uma ação política do poder administrativo, mas como uma forma de articulação em que os atores relacionaram-se dialógica e intersubjetivamente em busca de soluções para os extratores de samambaia silvestre. E assim, caracterizando-se como um caso prático de cidadania deliberativa, no qual ocorreu uma apropriação pelos indivíduos do direito de construção democrática do seu próprio destino (TENÓRIO, 2005).

Todos os atores locais, indistintamente, aprenderam com esse processo, pois houve respeito mútuo entre as diferentes pessoas. O processo de construção dessa experiência ocorreu em meio a uma gestão fluida e flexível, sem a qual, provavelmente, não se concretizaria o programa. Como bem mostra Woolcock (1998), a integridade organizacional do estado é uma das mais importantes bases para que as iniciativas dos indivíduos sejam canalizadas em direção a projetos coletivos. Este tipo de iniciativa tem a vocação de propiciar o surgimento de uma realidade intermediária entre o estado e o município, capaz de articular as ações necessárias à formação e ao desenvolvimento de uma rede territorial (ABRAMOVAY, 2000).

Por fim, parece relevante citar o comentário feito com frequência durante o estudo por diferentes atores sobre o município vizinho. Iguape, município localizado na vizinhança de Ilha Comprida, passa por desafios e potenciais semelhantes, fez diversas tentativas para fomentar um programa semelhante para os seus extratores. Contudo, não houve êxito nesta empreitada e isso tem intrigado os gestores locais, bem como os próprios extratores, conforme declarou um deles: "uma coisa que a gente tinha vontade era a liberação de Iguape, se a turma de lá vem para cá por que a gente não pode tirar lá?” Nesse sentido, permanecem questões não respondidas, conforme nos alertou Dowbor (2006): "como dinamizar estas iniciativas, dar-lhes escala, replicabilidade, efeitos multiplicadores? Como gerar um terreno mais favorável à inclusão produtiva do andar de baixo da economia, no 'circuito inferior"?"

De fato, parece haver em torno destas questões um campo fértil para pesquisas futuras. Ainda que o processo decisório seja um tema tradicional no campo administrativo, consideram-se necessários estudos que abordem as práticas dos gestores públicos e demais atores envolvidos no processo de construção e implantação de políticas públicas. Defende-se que os pequenos municípios não têm apenas dificuldades, mas também lições e aprendizados que são úteis ${ }^{8}$ aos outros municípios ou mesmo para os outros níveis de governo.

${ }^{8}$ A iniciativa de inclusão digital desenvolvida em Piraí-RJ, pequeno município fluminense, por exemplo, é a principal referência de inclusão digital no Brasil na atualidade. O governo Federal, assim como diversos municípios brasileiros, têm utilizado os 


\section{Referências}

ABRAMOVAY, R. Discutiendo la dimensión local. Las coordenadas del debate. In: Descentralizacion y Desarrollo Local. Cuadernos del CLAEH. Revista Uruguaya de Ciencias Sociales, n. 48, 2 série, Ano 13, n. 1-2, pp.7-16, 1988.

O capital social dos territórios: repensando o desenvolvimento rural. Economia Aplicada. vol. IV n. 2, p. 379397. São Paulo: FEA. Ribeirão Preto SP - abril/junho, 2000.

Conselhos além dos limites. Estudos Avançados. São Paulo: IEA/USP, vol. 15, n. 43, 2001.

Para uma teoria de los estúdios territoriales. IN: MANZANAL, M.; NEIMAN, G., LATTUADA, M. Desarrollo rural: organizaciones, instituciones y territorios. Ediciones Ciccus, Buenos Aires, pp. 51-70, 2006 Disponível em http://www.abramovay.pro.br/artigoscientifico/2006.

BEHN, R. D. Management by Groping Along. Journal of Policy Analysis and Management, v. 7, n. 4, p. 643-663, 1988.

BERG, L. Bruce. Qualitative Research Methods for the Social Sciences. 5th edition, Pearson, 2004.

BORINS, S. Public Management Innovation: Towards a Global Perspective. Toronto: University of Toronto, 2001. Disponível em: www.utsc.utoronto.ca/ mgmt/research/working-papers/wp2001-4.PDF. Acesso em: 7 jan. 2007.

CARVALHO, Márcio André de. Uma Introdução à Análise de Políticas Públicas: Análise Custo-Benefício, Árvores de Decisão e Modelos de Multiatributos. Brasília: Anais do XXIX ENANPAD, 2005.

CASSAB, L. A. História Oral: miúdas considerações para a pesquisa em serviço social. Londrina: Serviço Social em Revista, v. 5, n. 2, Jan/Jun, 2003. Disponível em: www.ssrevista.uel.br/c_v5n2_latif.htm. Acesso em: 12 dez. 2007.

COHEN, M. D.; MARCH, J. G.; OLSEN, J. P. A Garbage Can Model of Organizational Choice. Administrative Science Quarterly, v. 17, n. 1, p. 1-25, 1972.

COLEMAN, J. S. Foundations of Social Theory: The Belknap Press of Harvard University Press - Cambridge, Londres, 1990.

DOWBOR, L. Gestão social e transformação da sociedade, 1999. Artigos on line. Disponível em: http://dowbor.org/8_gestaosocial.asp. Acesso em: 20.08.2009.

Redes de apoio ao desenvolvimento local: uma estratégia de inclusão produtiva, setembro 2006. Artigos on line. Disponível em: http:// dowbor.org/06redesinclprodutivab.doc. Acesso em: 02.04.2011.

EISENHARDT, K. M. Building Theories From Case Study Research. The Academy of Management Review; v. 14, n. 4. Academy of Management, Oct, 1989.

FISCHER, T.; MELO, V. P. Programa de Desenvolvimento e Gestão Social: uma construção coletiva. In FISCHER, T.; ROESCH, S.; MELO, V. P. Gestão do desenvolvimento territorial e residência social: casos para ensino. Salvador: EDUFBA, CIAGS/UFBA, 2006.

aprendizados, os erros e os acertos de Piraí, para aperfeiçoarem e disseminarem projetos e programas de inclusão digital (IIZUKA, 2008).

${ }^{8}$ A iniciativa de inclusão digital desenvolvida em Piraí-RJ, pequeno município fluminense, por exemplo, é a principal referência de inclusão digital no Brasil na atualidade. O governo Federal, assim como diversos municípios brasileiros, têm utilizado os aprendizados, os erros e os acertos de Piraí, para aperfeiçoarem e disseminarem projetos e programas de inclusão digital (IIZUKA, 2008). 
FRANÇA FILHO, G. C. Definido Gestão Social. In: SILVA JR, J. T.; MÂISH, R. T.; CANÇADO, A. C. Gestão Social: Práticas em debate, teorias em construção. Fortaleza: Imprensa Universitária, 2008.

GOLDEN, O. Innovation in public sector human service programs: The implications of innovation by "groping along". Journal of Policy Analysis and Management, v. 9, n. 2, p. 219- 248, 1990.

GONDIM, S. M. G., SÁ, M. O., MELO, L. C. T., BARBOSA, S. T., VASCONCELlOS, C. M. GOEMS, S. T. Da Descrição do Caso à Construção da Teoria ou da Teoria à Exemplificação do Caso? Uma das Encruzilhadas da Produção do Conhecimento em Administração e Áreas Afins. Revista Organizações e Sociedade, v. 12, n. 3, out./dez., Salvador: Escola de Administração da Universidade Federal da Bahia, 2005.

HABERMAS, J. Teoria de la acción comunicativa I: Racionalidad de La acción y racionalización social. Madri: Taurus, 1987a.

Teoria de la acción comunicativa II: Crítica de la razón funcionalista. Madri: Taurus, 1987b.

Consciência moral e agir comunicativo. Rio de Janeiro (RJ): Tempo Brasileiro, 1989.

Mudança estrutural da esfera pública: investigações quanto a uma categoria da sociedade burguesa. Rio de Janeiro: Tempo Brasileiro, 2003.

HOPPEN, N.; LÖBLER, M. L.. Processo Decisório em Organizações no Brasil: Um Exame dos Estudos Realizados entre 1993-2002. Salvador: Revista Organizações e Sociedade, v. 11, n. 29, p. 49-70, 2004.

IBGE. Indicadores Sociais Municipais. Brasília: IBGE, 2000. Disponível em: www.ibge.gov.br/home/estatistica/populacao/indicadores_sociais_municipais/default.shtm. Acesso em: 12 mar. 2006.

População: Estimativas para a População em $1^{\circ}$ Julho de 2005 - Tabela de Estimativas por Município. Informações obtidas no site: www.ibge.gov.br. Acesso em: 17 fev. 2006. ago. 2007.

Site Cidades @. Brasília: IBGE, 2007. Disponível em: www.ibge.gov.br/cidadesat/default.php. Acesso em: 22

IIZUKA, E. S. Fluxos de Ações e Processos Decisórios na Gestão Pública Local: Estudos de Casos de Projetos e Programas Inovadores em Municípios de Pequeno Porte Populacional. São Paulo: Fundação Getulio Vargas. Tese de doutorado, 2008.

O Fluxo de Ações e o Processo Decisório na Política Pública Local: Estudo de Caso em Ilha Comprida-SP. In: Encontro Nacional dos Pesquisadores em Gestão Social, 4 2010, Lavras-MG. Anais .... Lavras-MG: Universidade Federal de Lavras-MG, 2010. v. Único. p. 1-336.

LAKATOS, E. M.; MARCONI, M. A. Metodologia do trabalho científico. 6. ed., São Paulo: Atlas, 2001.

LEITÃO, S. P. A Decisão na Academia I. Revista de Administração Pública, v. 27 n.1, p. 69-86, Rio de Janeiro: EBAPE, FGV, 1993.

A Decisão na Academia II. Revista de Administração Pública, v. 27, n. 2, p. 158-182, Rio de Janeiro: EBAPE, FGV, 1993.

O Poder no Contexto da Decisão Organizacional. Revista de Administração Pública, v. 30, n.2, p. 137-151, Rio de Janeiro: EBAPE-FGV, 1996.

LINDBLOM, C. E. Policy Analysis. The American Economic Review, v. 48, n. 3, p. 298- 312, 1958.

MINTZBERG, H. Patterns in strategy formation. Management Science, v. 24, n. 9, p. 934-948, Maryland: 1978. 

272,1985

WATERS, J. A. Of Strategies, Deliberate and Emergent. Strategic Management Journal, v. 6, n. 3, p. 257 -

MORÇÖL, G. (Org.). Handbook of Decision Making. Flórida: CRC Press, Taylor e Francis Group, 2007.

MOTTA, P. R. Razão e Intuição: Recuperando o Ilógico na Teoria da Decisão Gerencial. Rio de Janeiro: Revista de Administração Pública, 22 (3), p. 77-94, 1988.

MOYANO, E. E. El concepto de capital social y su utilidad para el análisis de las dinámicas del desarrollo. Economia Ensaios, v.13, n.2 e v.14, n.1: 3-39, Uberlândia, 1999.

NEYLAND, D.; SURRIDGE, C. Do universities work? Inglaterra: AUA Annual Conference, Derby, 2003. Disponível em: www.reading.ac.uk/evince/output. Acesso em: 10 fev. 2007.

PUTNAM, R. D. Comunidade e Democracia: A experiência da Itália Moderna. Editora da Fundação Getúlio Vargas, Rio de Janeiro, 1996.

Bowling alone. The collapse and revival of American community. New York, Simon \& Schuster, 2000.

RATTNER, H. O Resgate da Utopia. Palas Atenas, 2005.

SEN, A. Desenvolvimento como Liberdade. São Paulo: Companhia das Letras, 2000.

SIMON, H. A. Theories of Decision-Making in Economics and Behavioral Science. The American Economic Review, v. 49 , n. 3, p. 253-283, 1959.

Comportamento Administrativo: Estudo dos Processos Decisórios nas Organizações Administrativas. Rio de Janeiro: Serviço de Publicações da Fundação Getulio Vargas, 1965.

. Administrative Decision Making. Public Administration Review, v. 25, n. 1, Twenty-Fifth Anniversary Issue, p. 31-37, 1965.

On How to Decide What to Do. The Bell Journal of Economics, v. 9, n. 2, p. 494-507, 1978.

SOARES, M. I. L.C. Manejo Participativo para Exploração Sustentável da Samambaia Silvestre. In: BARBOSA, H. B.; SPINK, P. 20 Experiências de Gestão Pública e Cidadania: Ciclo de Premiação 2001.. São Paulo: Programa Gestão Pública e Cidadania, EAESP - FGV, 2002.

SPINK, M. J. Pesquisando no cotidiano: recuperando memórias de pesquisa em Psicologia Social. Psicologia \& Sociedade, v. 19, n. 1, Porto Alegre: Associação Brasileira de Psicologia Social, 2007. Disponível em: http://www.scielo.br/ scielo. php? script= sci_arttext\&pid=S0102-71822007000100002\&lng=en\&nrm=iso. Acesso em: 28 jan. 2008.

SPINK, P. K. A Forma do Informal. Revista Psicologia e Sociedade. São Paulo: Associação Brasileira de Psicologia Social, p. 99-107, 1989.

TENÓRIO, F. G. Cidadania e desenvolvimento local: casos brasileiros. IX Congreso Internacional del CLAD sobre la Reforma del Estado y de la Administración Pública, 9. In: Proceedings... Madrid, España, 2 - 5 Nov. 2004.

(Re)visitando o conceito de gestão social. Desenvolvimento em Questão, jan.jun, ano/vol. 3, n. 005. Universidade Regional do Noroeste do Estado do Rio Grande do Sul, Ijui, pp. 101-124, 2005.

Tem razão a administração? 3 Ed. Ijuí: Editora da Unijuí, 2008a.

Um espectro ronda o terceiro setor: o espectro do mercado. 3 Ed. Ijuí: Editora da Unijuí, 2008b. 
Gestão social: uma réplica. Revista ADM. MADE. Rio de Janeiro: Universidade Estácio, ano 9, v.13, n.2, p.14, maio/agosto, 2009.

Gestão Social: uma réplica. In RIGO, A. S.; SILVA JÚNIOR, J. T.; SCHOMMER, P. C.; CANÇADO, A. C. Gestão Social e Políticas Públicas de Desenvolvimento: Ações, Articulações e Agenda. Recife: UNIVASF, 2010.

VERENA, A. Manual de História Oral. Rio de Janeiro: Ed. FGV, 2004.

VERGARA, S. C. Sobre a intuição na tomada de decisão. Revista de Administração Pública, v. 27, n.2, p. 130-57, 1993.

Métodos de Pesquisa em Administração. São Paulo: Atlas, 2005.

VIEIRA, M. M. F. Por uma boa pesquisa (qualitativa) em administração. In: Pesquisa qualitativa em administração. Marcelo Milano Falcão Vieira; Deborah Moraes Zouain (Org.). Rio de Janeiro: Ed. FGV, 2004.

WEICK; K. Sensemaking in Organization. London: Sage Publications, 1995.

WOOLCOCK, M. Social capital and economic development: toward a theoretical sythesis and policy framework. Theory and Society: Renewal and Critique in Social Theory, v. 27, n. 2, p. 151-208, 1998.

YIN, R. K. Estudo de Caso: Planejamento e Métodos. 3. ed., Porto Alegre: Bookman, 2005. 